\title{
Erken Dönem İslâm Düşünce Geleneğinde Fârâbî Felsefesi ve Mantığ1
}

Al-Fârâbî's Philosophy and Logic in the Early Period of Islamic Thought

\author{
Tradition
}

\section{Ali ÇETIN}

Doç. Dr., Kırıkkale Üniversitesi, İslâmi İlimler Fakültesi, Kırıkkale/Türkiye Associate Professor Dr., Kırıkkale University, Faculty of Islamic Sciences, Kırıkkale/Türkiye alicetintr@gmail.com | orcid.org/0000-0002-8621-7221 | ror.org/01zhwwf82

$\begin{array}{rl}\text { Makale Bilgisi } & \text { Article Information } \\ \text { Makale Türü } & \text { Article Type } \\ \text { Araştırma Makalesi } & \text { Research Article } \\ \text { Geliş Tarihi } & \text { Date Recieved } \\ 15 \text { Ekim 2021 } & 15 \text { October } 2021 \\ \text { Kabul Tarihi } & \text { Date Accepted } \\ 29 \text { Aralık } 2021 & 29 \text { December } 2021 \\ \text { Yayın Tarihi } & \text { Date Published } \\ 31 \text { Aralık 2021 } & 31 \text { December 2021 } \\ \text { İntihal } & \text { Plagiarism } \\ \text { tespit edilmemiştir. } & \text { software. No plagiarism detected. } \\ \text { Etik Beyan } & \text { Ethical Statement } \\ \text { Bu makale, iTenticate yazılımı ile taranmıștı́ntihal } & \text { This article has been scanned with iTenticate } \\ \text { Bu çalışmanın hazırlanma sürecinde bilimsel ve etik } & \text { It is declared that scientific and ethical principles } \\ \text { ilkelere uyulduğu ve yararlanılan tüm çalışmaların } & \text { have been followed while carrying out and writing } \\ \text { kaynakçada belirtildiği beyan olunur (Ali Çetin). } & \text { this study and that all the sources used have been } \\ & \text { properly cited (Ali Çetin). } \\ \text { CC BY-NC-ND 4.0 lisansı ile lisanslanmıştır. } & \text { Licensed under CC BY-NC-ND 4.0 license. }\end{array}$

Atıf $\mid$ Cite As

c Çetin, Ali. "Erken Dönem İslâm Düşünce Geleneğinde Fârâbî Felsefesi ve $\begin{array}{lllll}\text { Mantı̆̆ı". } \quad K a d e r & \text { 19/2 (Aralık 2021), } & \text { 702-726. }\end{array}$ https://doi.org/10.18317/kaderdergi.1009997 


\title{
Öz
}

Felsefe ve mantık, Hıristiyan düşünce geleneğinden farklı olarak, İslâm kültüründe güçlü bir irade sonucu ve herhangi bir sınırlamaya tabi olmadan gelişmiştir. Tarihin gördüğü en büyük entelektüel atılım olarak Eski Yunan, Süryani, Pers, Yahudi ve Hind düşüncesinin önemli kültürel içerikleri, çeviri hareketleri çerçevesinde, Arapçaya aktarılmıştır. Bu bağlamda bazı kültürel unsurlar, söz gelimi kelâm, felsefî düşüncenin kabulü ve anlaşılmasında etkili de olmuştur. Çevirilere konu olan içerik başlangıçta, tıp, astronomi, kimya ve matematik gibi alanlarla ilgili olsa da bunlarla bağlantılı felsefe ve mantık unsurları da sürece eklenmiştir. Aristoteles' in derin etkisi mantığın, Meşşâ̂ biçimiyle İslâm kültüründe yaygınlaşmasını sağlamış ve bu bağlamda felsefeciler ile bazı kelâmcılar arasında güçlenmesinin yolunu açmıştır. Bu süreçte içeriğin özellikle kısıtlanmadan aktarılması, özgür bir entelektüel ortamın bulunması, Müslüman düşünürlerin bunlara erişimini kolaylaştırmış, onların özgün katkılar sunmalarını sağlamıştır. Bu bağlamda mantık, zamanla, kelâm, dil ve fikıh gibi disiplinlerle etkileşim halinde olmuştur. Özellikle Fârâbî’nin (öl. 339/950) tasarladığı biçimiyle mantık, İslâm entelektüel geleneğinde özgün bir alan haline gelmiştir. Fârâbî, tıpkı Aristoteles gibi, mantığı doğruluğun bir ölçütü olarak kurgulamak istemiş, onu diğer bilimler için kullanılabilir kılma adına, kavramlar ve yargılar düzleminde ortaya koymuştur. Güçlü mantık kurgusu, sadece felsefe değil diğer İslâmî ilimler için de sağlam bir temelin oluşmasına katkı sağlamıştır. Bu anlamda İslâm felsefesinin ve mantığının anlaşılması, Fârâbî düşüncesini daha yakından ve farklı bağlamlarda incelemeyi gerektirmektedir. Çalışmamızda felsefe ve mantığın İslâm öncesi kökenlerini kısaca ele alacağız ve bu düzlemde genel olarak Fârâbînnin söz konusu geleneğe katkılarını Tanrı, bilimlerin tasnifi, mantığın felsefî boyutu gibi temel bazı konular çerçevesinde incelemeye gayret edeceğiz.

Anahtar Kelimeler: İslâm Felsefesi, Mantık, Felsefe ve Kelâm ilişkisi, Mantık ve Felsefe ilişkisi, Fârâbî.

\begin{abstract}
The Philosophy and logic in Islamic thought, unlike Christian culture, developed uncensored and as a result of great demand. After the biggest translation movement in history, important components of Ancient Greek, Syriac, Persian, Jewish and Hindu cultures were transferred to Arabic. Kalam, which developed earlier in Islamic culture, has also been effective in understanding and accepting the philosophical content. In the beginning, translations were made in fields such as medicine, chemistry, astronomy and mathematics. Philosophy literature was also translated into Arabic due to its close relationship with other sciences and the need to fill the "gaps" in Islamic culture. The philosophy of logic was also transferred to Arab culture in its Aristotelian form. Especially the great influence of Aristotle helped strengthen the thought of logic among Arab philosophers and some theologians. As with other translation content, the logic has been translated into Arabic without any censorship. Contrary to the thinkers of Christian culture, Islamic philosophers learned all the subtleties of logic in a free intellectual environment, and as a result, this fact created a way for them to make a unique contribution to the discipline of logic. Logic, as it has been transformed into Arabic elements in Islamic culture, has been influential in basic areas such as theology, language, figh and kalam. In this process, logic, which was handled intertwined with traditional philosophy, has progressed to become a refined thought, especially with the influence of the first great philosopher Fârâbî. Fârâbî is not only a great philosopher but also a great Islamic scholar, and these qualities enabled him to adapt logic to Arab culture and Islamic sciences from his Aristotelian roots. Fârâbî, just like Aristotle, wanted to use logic as a criterion of truth for philosophical fields. Fârâbî, who designed logic under two main headings such as concepts and judgments, adapted logic to Arab culture for Muslims in the reasoning process. This solid construction of logic not only strengthened philosophical thought, but also contributed to the later establishment of a solid structure in Islamic sciences. In this context, the understanding of Islamic philosophy and its transformation with the effect of logic require a close examination of Fârâbî's thought. In our article, we will briefly discuss the pre-Islamic origins of philosophy and logic, and on this plane, we will examine Fârâbî's contribution to philosophy of some basic issues such as God, the classification of sciences, and the philosophical dimension of logic and try to reveal his effects on Islamic culture from a general point of view.
\end{abstract}

Keywords: Islamic Philosophy, Logic, Relationship between Philosophy and Kalam, the Relation between Logic and Philosophy, Al-Fārābī. 


\section{Giriş}

Mantık, en genel anlamda, düşünce içeriklerinin biçimsel olarak doğruluk, tutarlılık ve geçerlilik gibi açılardan incelenmesini sağlayan, sistematik bir denetim, ölçüm aracıdır. Bu çerçevede mantık, geleneksel perspektifte ve felsefî, bilimsel içerik bağlamında, özel bir bilgi teorisini içerdiği gibi kendisi de felsefenin bir konusu olarak ortaya çıkar. Epistemik mantık formuyla disiplin, bilgi, inanç ve bağlantılı pek çok kavramını içerdiği için epistemolojinin de ilgi alanındadır. Aristoteles'in kurguladığı biçimiyle mantık, hatâbî ve cedelî süreçlerden başlayarak İkinci Çözümlemeler'in iddialı kuramı olan kesinlik idealine kadar bir dizi felsefî konularda etkilidir. Bu etkinin tarihi, erken dönemle sınırlı da değildir. Mantığın genel kavramları ve özellikle modal kavramlar ve doğruluğun iki değerli biçimi, klasik bilimler üzerine gölgesini düşürürken aynı zamanda Orta Çağ ve modern dönemlerde de bilginin kurgulanışında etkili olmuştur. Belkemiğini Aristotelesçi yaklaşımının oluşturduğu klasik mantığın, günümüzün yeni mantık kurgularının yanında ikinci planda kaldığı kanısı yaygın biçimde kabul görse de insanın dil, bilgi ve diğer felsefî kavramlarla kurduğu ilişkiler göz önünde bulundurulduğunda hatta bir bütün olarak insan-dünya ilişkisi söz konusu olduğunda, vazgeçilmez bir konuma sahip olduğu anlaşılacaktır.

Aristoteles'ten sonra çeşitli katkılarla gelişen mantık, İslâm düşüncesinin ilgi sahasına da diğer disiplinlerle birlikte girmiştir. Aristoteles'in Süryani yorumcularına göre mantık, daha sonra yaygın biçimde, İslam filozoflarının da benimseyeceği üzere, her biri farklı konuya tekabül eden dokuz ayrı bölüm olarak incelenmiştir:

\begin{tabular}{lll} 
Konu & Arapça & Orjinal \\
\hline Giriş & İsâgûci/Medhal & İsagoge \\
Kavramlar & Mekûlât & Categoriae \\
Önermeler/Yorum & İbâre & Peri Hermeneias \\
Çözümlemeler/Analitik & Kiyâs & Analytica Priora \\
İspat/Kesinlik & Burhân & Analytica Posteriora \\
Topikler/Tartışma & Cedel & Topica \\
Safsata & Mugâlata & Sophistici Elenchi \\
Söz sanatları & Hitâbe & Rhetorica \\
Şiir & Şi'r & Poetica \\
\end{tabular}

Yukarıdaki biçimiyle kristalize olan mantık kurgusu, Aristoteles'in kendi dönemine benzer biçimde etkili olmuştur. İslâm entelektüel aklının gelişimine katkı sunan mantığın, örneğin kelâmda Eş'arî ve fikıhta Şafiî gibi gelenekselci öncüler üzerindeki kısıtlı olan etkisi daha sonraki süreçte, bütün bilgin ve disiplinler düzeyinde artarak devam etmiştir.

Çalışmamızın konusu olan Fârâbî, felsefe ve özellikle mantık düzleminde İbn Sînâ'nın derin etkisinden önce, söz konusu disiplini olgunlaştıran düşünürdür. Fârâbî üzerine doğrudan, dolayll,

Nicholas Rescher, Studies in the History of Arabic Logic (Pittsburgh: University of Pittsburgh Press, 1963), 13. 
dilimizde ve diğer dillerde sayısız çalışmalar kaleme alınmıştır. ${ }^{2}$ Bütün bu çalışmalar bağlamında denilebilir ki Kıftî'nin (öl. 646/1248) işaret ettiği gibi Fârâbî, özellikle mantık bağlamında ihmal edilen ya da kapalı bir biçimde ortaya konulan pek çok içeriği açıklığa kavuşturmuştur. ${ }^{3} \mathrm{Bu}$ anlamda Fârâbînnin anlaşılması, yapının temel dayanaklarının daha iyi kavranılmasını sağlayacaktır. Çalışmamızda, Fârâbî düşüncesini hazırlayan etmenleri, bu bağlamda söz konusu içeriğin temel yapı taşlarını, İslâm kültür bileşenlerinin konuyla ilgili yönlerini, bütüncül biçimde ele alacağız. Aydınlatmaya çalıştığımız nokta, dile getirilen dizgelerde Fârâbînnin konumu, etkisi ve katkısıdır.

Bu çalışmalardan bazıları şunlardır: Dieterici, F., ed. Al-Fârâbî's philosophische Abhandlungen (Leiden: E. J. Brill, 1890); Haddad, Fuad."Al-Fârâbî's Theory of Language." American University of Beirut Festival Book (Festschrift). ed. Fuad Sarraf and Suha Tamin (Beirut, 1967); Mahdi, Muhsin, tr. Al-Fârâbî's Philosophy of Plato and Aristotle (Ithaca: Cornell University Press, 1969); Von Grunebaum, G. E., ed. Logic in Classical Islamic Culture (Wiesbaden, 1970); Zimmermann, F. W. AlFârâbî's Commentary and Short Treatise on Aristotle's De Interpretatione (Oxford: Oxford University Press, 1981); Shukri Abed, Aristotelian Logic and the Arabic Language in Al-Fârâbî (Albany: State University of New York Press, 1991); Davidson, Herbert. Alfârâbî, Avicenna, and Averroes on Intellect. Their Cosmologies, Theories of Active Intellect, and Theories of Human Intellect (Oxford: Oxford University Press, 1992); Majid Fakhy, Al-Fârâbî, Founder of Islamic Neoplatonism: His Life, Works and Influence (Oxford: One world Publications, 2002); Robert Hammond, Fârâbî Felsefesi ve Ortaçăg Düşüncesine Etkisi, çev. Uluğ Nutku ve Gülnihal küken (İstanbul: Alfa Yayınları, 2001); Nihat Keklik, İslâm Mantık Tarihi ve Fârâbi Mantığı (İstanbul: İstanbul Üniversitesi Edebiyat Fakültesi Yayınları, 1969); Mübahat Türker Küyel, Fârâbî'nin Bazı Mantık Eserleri (Ankara: Atatürk kültür Merkezi, 1990);; Naci Bolay, Fârâbî ve İbni Sina'da Kavram Anlayışı (İstanbul: MEB, 1990); Orhan Hülagü, Fârâbî ve İbn Haldun'da Devlet Düşüncesi (İstanbul: Kırkambar Kitaplığı, 1999); Burhan Ulutan, Fârâbî Felsefesi (İstanbul: TDAV Yay., 1999); Fahrettin Olguner, Fârâbî (İstanbul: Ötüken Neşriyat); Şahin Filiz, Fârâbî (İstanbul: İnsan Yay., 2005); Lokman Çilingir, Fârâbî ve İbn-i Haldun'da Siyaset (İstanbul: Araştırma Yay., 2009); Cavit Sunar, İslâmda Felsefe ve Fârâbî (İstanbul: Anadolu Aydınlanma Vakf1, 2006); Nejdet Durak, Platon ve Fârâbî Felsefesinde Erdem Kavramı (Isparta: Fakülte Kitapevi, 2009); Yaşar Aydınlı, Fârâbî (İstanbul: İsam Yay., 2017); H. Gazi Topdemir, Fârâbî (İstanbul: Say Yay., 2017); Zeki Aktaş, Fârâbî ve John Locke'un Ahlak Felsefeleri (Karşlaştırmalı Bir İnceleme) (Ankara: Çizgi Kitapevi, 2018); Bekir Karlığa, Bir Medeniyet Düşünürü: Fârâbî ( İstanbul: İşaret Yay., 2019); Mustafa Yeşil, Fârâbî ve Quine'da Dil Anlam ve Doğruluk ìlişkisi (isstanbul: Litera Yay. 2019); Şenol Korkut, Fârâbî ve İbn Sinâ (İstanbul: Çıra Yay., 2020); Bunların dışında Yapılmış doktora tezleri de anılmaya değerdir. Bazı tezlerin yazarları ve tez adları şöyledir: Eyüp Şahin, Fârâbînin Zihin Felsefesi, Ankara Üniversitesi, 2003; Mehmet Kasım Özgen, Fârâbînin Mutluluk Anlayıısı, Erciyes Üniversitesi, 2005; Şenol Korkut, Fârâbî'nin Siyaset Felsefesinin Temel Problemleri ve Kökenleri, Ankara, 2005; M. İslâmîl Rızvanoğlu, Fârâbîde Îkâ Teorisi, Marmara Üniversitesi, 2007; Hasan Ocak, İslâm Felsefesinde İnsanın Özgürlïğü Problemi (Fârâbî ve Kadı Abdulcebbar'a göre), Selçuk Üniversitesi, 2009; Ayşe Taşkent, Fârâbî, İbn-i Sina ve Ibn-i Rüşd'te Estetik, Marmara Üniversitesi 2009; Mustafa Yıldız, Fârâbî’nin Toplum ve Devlet Görüşü, Erciyes Üniversitesi, 2009; Suat Çelikkol, Fârâbîde Ahlak ve Ahlak Eğitimi, Erciyes Üniversitesi, 2010; Fatma Dore, Fârâbînin Dil ve Anlam Kuramı, Marmara Üniversitesi, 2011; Hümeyra Özturan, Aristoteles ve Fârâbî'de Ahlâkın Kaynağı Problemi, Marmara Üniversitesi, 2013; Ali Tekin, Aristoteles ve Fârâbî'de Burhân Teorisi, Marmara Üniversitesi, 2014; Mehmet Murat Karakaya, Plotinus'un Esûlûciya Üzerinden Fârâbî'ye Etkisi, Ankara Üniversitesi, 2016; Mirpenç Akşit, Fârâbî'de Mantığın Dili ve Dilin Mantığı Üzerine Bir Anlam Arayışı, Atatürk Üniversitesi, 2017; Enes Taş, Fârâbî ve İbn Sinâ'da Bireyleşme İlkesi Bağlamında Nefis Beden İlişkisi, Uludağ Üniversitesi 2017; Yunus Öztürk, Kelâm-Metafizik ìlişkisi (Fârâbî eksenli bir inceleme), Hitit Üniversitesi, 2019; Özkan Kerimoğlu, Fârâbî ve İhvan-ı Safa'da Siyaset ve Siyaset Ahlakı, Atatürk Üniversitesi, 2020; Nursema Kocakaplan, Fârâbî ve İbn-i Sina'da Tahayyül Kavramı, Uludağ Üniversitesi, 2021; Muhammet Nasih Ece, İbn Bâcce Mantığı ve Fârâbî Bağlantıları (Konya: Çizgi Yayınları, 2021); Muhammet Nasih Ece, “Fârâbî'de Mantık Bilimine İlişkin Bazı Temel Meseleler", Bilimname 37 (2019/1).

3 Ebü'l-Hasan Cemaleddin Ali b. Yusuf b. İbrahim el-Kiftî, İhbâru'l-ulemâ bi ahbâri'l-hukemâ, thk. İbrahim Şemseddin (Lübnan: Daru'l-Kütübi'l-İlmiyye, 2005), 210. 
Çalışmamızda yöntemsel olarak klasik döneme ait olanın doksografik bir terkibinden çok bunun üzerine eserleriyle eklemlenen Fârâbî’nin özgün ve özgül ağırlığının analizi bağlamında bir usul takip etmeye çalışacağız.

\section{1. İslâm Kültüründe Mantık ve Felsefe'nin Tarihsel Arka Planı}

\section{1. İslâm Öncesi Dönem}

Peripatetiklerin mantık sistemi temelde, Aristoteles'in daha sonra Organon olarak adlandirılan çalışmalarına ve ikinci adımda da Roma döneminde yaşamış yorumcuların çeşitli şerhlerine dayanmaktadır. Genel anlamda Antik mantık öğretisi ikiye ayrılmaktadır. Bunlar, doğrudan Aristoteles'in eserlerine dayanan yapı ve diğeri de Stoacı mantık anlayışıdır. Aristotelesçi mantık, Organon külliyatını ve daha sonra onun genişletilmiş biçimini içermektedir. Özellikle İslâm mantıkçıları tarafından ince biçimde örüntülenen mantık, 13. yüzyılda Skolastik geleneğe de nüfuz etmiştir. Diğer taraftan Stoacı mantık ise karşllıklı argümantasyon süreçlerini içeren diyalektik ve onun tersi biçimde sunulan ve sosyal alanda gerçekliğin/doğrunun ortaya çıkarılmasını amaçlayan ve buna yönelik kanunları betimleyen retorikten oluşmaktadır. ${ }^{4}$ Stoa, aynı zamanda tanım ve diyalektik çalışmalarının doğası üzerinde de durmuştur. Özellikle konuşma temelli yapının mantıksal içerimleri ve bu açıdan dil ya da gramer, diğer taraftan önermesel mantık ve onun bileşenleri ayrıca önemle üzerinde durulan konular olmuştur. ${ }^{5}$

Aristoteles'in eserleri daha sonra gelen takipçileri tarafından kurtarılmıştır. Bunun aksine Stoa'nın, Chrysippus (öl. MÖ. 206) gibi mantıkçılarının eserleri ise sonraki nesillere çeşitli eserlerdeki nakiller dışında ulaşmamıştır. Bu nakiller de Orta Çağ düşüncesine aktarılamamıştır. Özellikle Aristoteles'in öğrenci ve takipçisi Theophrastus (öl. MÖ. 287) hocasının eserlerine yorum düzeyinde katkı sunmuştur. Aristoteles mantığı geç Antik dönem ve Stoa mantığının çeşitli yönlerini de içererek Romalılardan Cicero (öl. MÖ. 43) orta Platoniklerden Apuleius (öl. 170), Yeni Platonculardan Plotinus (öl. 270), Porphyry (öl. 305), Themistus (öl. 388), Galenciler ve Boethius (öl. 524) üzerinden gelişimine devam etmiştir. ${ }^{6}$

Yukarıdaki süreçte söz gelimi Bizanslı düşünürler de Geç Antik gelenekte olduğu gibi Aristoteles’i yorumlamışlardır. Bu yorumlar, Helenistik felsefenin Hıristiyan öğretisine yönelik yaklaşımları da barındırmaktadır. Bu düşünürler, felsefî yazmaları Yunan dilinde çoğaltmışlardır. Bu çaba, çoğu antik eserin orijinal dilindeki haliyle günümüze kadar ulaşmasını sağlamıştır. Bununla birlikte Batı'da erken dönemlerde Latince, felsefenin biricik dili olmuş ve sonrasında Yunanca kaynaklı içerik ikinci planda kalmıştır. Bunun sonucunda Geç Antik döneme kadar Latince yazan söz gelimi Augustine (öl. 430), Martianus Capella (öl. 6. yy) ve Boethius gibi düşünürler söz konusu geniş coğrafyada tek kaynak olarak kalmışlardır. Aristoteles'in pek çok eseri ve Platon'un neredeyse

Julie Brumberg- Chaumont, "The Legacy of Ancient Logic in the Middle Ages", ed. Catarina Dutilh Novaes and Stephen Read, The Cambridge Companion to Medieval Logic (Cambridge: Cambridge University Press, 2016), 20.

5 Marcia L. Colish, The Stoic Tradition From Antiquity to the Early Middle Ages: Stoicism in Christian Latin Literature, v. 1 (Leiden: Brill, 1985), $50 \mathrm{vd.}$

6 Brumberg-Chaumont, "The Legacy of Ancient Logic in the Middle Ages", 21. 
bütün çalışmaları Latin dünyasının çeşitli ülkelerinde doğrudan ulaşılamayan kaynaklar haline gelmiştir.?

\section{2. İslâm Kültüründe Mantık ve Felsefe}

Felsefî bir disiplin olarak İslâm mantığı, Eski Yunan mantığından tevarüs etmiş ve temelde Peripatetik geleneğe dayanan bir yapı olarak ortaya konulmuştur. Bu yapı, doğası gereği fikıh, dil, kelâm ve felsefe gibi rasyonel süreçleri içeren disiplinler ile yöntemsel ve pratik açıdan etkileşim içerisinde de bulunmuştur. Bu etkileşim, başlangıç itibariyle çatışma daha sonra da kabullenme çerçevesinde gelişen karmaşık bir ilişkiyi içermektedir. ${ }^{8}$

İslâm coğrafyasında kök salmaya başlayan felsefî düşünce ve yüzlerce yıllık geleneği olan mantık, Müslüman düşünürlerin ilgi alanlarına girmesiyle, bu yeni kültürün elinde evrilmiştir. İslâm düşüncesinin üzerine eğildiği Organon külliyatı ise Geç Antik dönemden itibaren İsagoci, Retorik ve Şiir gibi eserleri de bünyesine alan daha büyük bir içerik olarak belirmiştir. Bu gelenekler arasındaki ince fark, İslâm mantıkçılarının, seleflerinin aksine bu tasnifi şematik olarak anlamalarının ötesinde Organon külliyatının, mantığın bütüncül bir dizgesini sunmuş olduğuna inanmalarıdır. Arapça olarak ilk mantık çalışması ise özet biçiminde İbnü'l-Mukaffâ'ya (öl. 142/759) ya da oğluna atfedilmektedir. Süryani geleneğini yansitan söz konusu çalışma, Organon'un belli kitaplarından bazı bölümlerin kısaltılmış şeklini içermektedir. Yine bu çalışmada Arapça mantık terimlerinin ilk türlerinin ortaya konulduğu aktarılmaktadır. ${ }^{9}$

Dile getirilen Bizans ve Latin düşün geleneklerinin çalışmalarına ulaşım çabalarını ve bu bağlamdaki felsefî düşünce evrimini göz önünde bulundurduğumuzda, farklı bir yaklaşım olanağını ve biçimini İslâm kültür dünyasında bulmak mümkündür. Bu kültür havzasının düşünürleri, tıpkı Bizanslı muadilleri gibi inançlarını, çalışmalarına taşıyarak felsefeye kendi renklerini vermişlerdir. Felsefî düşünceye olan söz konusu katkıda yine Hıristiyan ve Yahudi filozofları da önemli bir rol üstlenmişlerdir. Hıristiyanlar, Arapça felsefî literatürün erken dönemdeki gelişiminde etkili olmuşlardır. Onlar, çevirmen olarak katkı sundukları gibi Hıristiyan öğeler eşliğinde biçimlendirilmiş Aristoteles felsefesinin, dönemlerine özgü ilk yorumcuları olarak da örneklik teşkil etmişlerdir. Yahudi filozofları da İslâm düşüncesi tarafından şekillendirilen topraklarda kendilerine özgü duruşlarıyla yer edinmişlerdir. Saadia Gaon (elFeyyûmî öl. 331/942) ve Maimonides (íbn Meymûn öl. 601/1204) bunlar arasında en bilinen örneklerdendir. ${ }^{10}$

Hz. Muhammed'in hicretinden sonra farklı bileşenlerle toplum olma vasfını kazanan, pek çok yönüyle eski fakat içine aldığı ruh yönüyle yeni yapı, birkaç yüz yıllık kısa sürede geniş bir coğrafyaya yayılmış, beraberinde Arap dilini de taşımıştır. Elbette Arapçanın önemi, Müslümanların kutsal kitaplarının olağan üstü edebi seviyesiyle dili domine etmesinden ve kutsallı̆̆ı açısından, onların zihinlerinde vazgeçilmez bir yapı olarak ortaya çıkmasından

Peter Adamson, Philosophy in the Islamic World, v. 3 (Oxford: Oxford University Press, 2016), 3.

Adamson, Philosophy in the Islamic World, 46.

Ahmad Hasnawi and Wilfrid Hodges, "Arabic Logic up to Avicenna", The Cambridge Companion to Medieval Logic, ed. Catarina Dutilh Novaes and Stephen Read (Cambridge: Cambridge University Press, 2016), 49.

10 Adamson, Philosophy in the Islamic World, 40. 
gelmiştir. Bu durum, belki de kaçınılmaz olarak Hıristiyan dünyasının aksine, felsefî literatürün Arapça yazılmasına yol açmıştır. Elbette süreçte, yükselen bir tür Arap milliyetçiliğinin de etkili olduğunu belirtmek gerekmektedir. Yukarıda anılan iki Yahudi düşünür de Arapça eserler kaleme almışlardır. Yine yerel diller, örneğin Farsça ve İbranice de İslâm kültürünün felsefî mirası içerisinde yer bulmuştur. Bu nedenle söz konusu kültür ürünlerine Arap felsefesi ya da İslâmî felsefe yerine genel kültürü imlemek üzere İslâm Düşüncesi ya da İslâm Felsefesi adlandırmasında bulunmak uygun olacaktır.

Temelde İslâm Felsefesini İbn Sînâ (öl. 428/1037) öncesi ve sonrası olarak adlandırmak mümkündür. Böyle bir adlandırmanın tarihsel açıdan haklılığı, onun çalışmalarının, İslâm kültür şemsiyesi altında felsefe anlayışındaki temel biçimlenme sürecinin de genel hatları bakımından son aşaması olmasına dayanmaktadır. Onun çalışmalarına kadar geçen süreçte, yani düşün kimliğinin kazanıldığı, özgün yönlerin yaratıldığı bu aşamada temel ilgi, Yunan felsefesine özellikle Aristoteles'e ait eserlerin çevrilmesi ve yorumlanması üzerine yoğunlaşmıştır. Bu sürecin de İbn Sînâ'dan önce en büyük iki direği Kindî (öl. 260/873) ve Fârâbî'dir. Özellikle bu iki filozof oldukça özgün bir tarzda söz konusu felsefî içeriği İslâm dininin önermeleriyle ve güçlü rakipleri olan Müslüman kelâmcıların inançlarıyla uzlaştırma yolunda gayret sarf etmişlerdir. Bu gayret o kadar derine nüfuz etmiştir ki daha önce Hıristiyan ve Yahudi filozofların temel dogmalarını Aristoteles ve Yeni Platoncu öğelere dayanarak biçimlendirme veya yeniden kayda değer yorumlama çabasına girmedikleri düşünüldüğünde, ortaya konulan içerik, büyük ve cesur bir adımın ürünüdür. İbn Sînâ ile neredeyse son bulan bu biçimlenme süreci, mantık ve fizikten başlayarak metafiziğin en ince detaylarına kadar inen ve felsefenin temel hatlarını kendi rengine boyayan bir yapıyı doğurmuştur. Bu yapı, İslâm düşüncesine hayat veren bütün sahaları ince ve dakik bir şekilde yeniden dokumakla kalmamış, kelâm ve tasavvuf gibi alanları derinden etkilediği gibi Orta Çă̆ düşüncesine de yön vermiştir.

Diğer taraftan not edilmesi gereken, tarihsel sürecin temel bileşenlerinden olan ve belki de yapının üzerinde filizlendiği toprak, felsefeye zemin hazırlayan verimli kültürel ortamdır. Bu kültür havzasında biten ve yeşeren İslâm düşüncesinde cari felsefî 1stılahlar, Arap dilinde tek seferde değil çeşitli merhalelerden sonra tedricen ortaya çıkmış ya da gelişmiştir.

Dile getirilen oluşumun pek çok bileşeni bulunmaktadır. Bu bağlamda çevirmenlerin ve Mu'tezile'nin etkisi oldukça önemlidir. Mu'tezile'nin İslâm kültüründe özellikle akla dayalı düşüncenin gelişiminde katkısı bulunmaktadır. Elbette insanoğlu, her türlü ediminde akla dayanmaktan geri duramaz fakat bizim burada dile getirdiğimiz akla dayanma kavramı, kültürel ve ideolojik yönlendirmelerin ötesinde, tutarlılık, neden-sonuç ilişkisini belli normlar çerçevesinde kurabilme, bu anlamda geçerli yargılara ulaşabilme ve aklı önceleme anlamındadır. Mu'tezilî bilginler, doğrudan dile getirdiğimiz anlamda, akla dayalı yargılarda bulunmuşlar, bu nedenle özgür düşüncenin, terimsel kullanımıyla rey ekolünün temsilcileri olmuşlardır. Bu bağlamda onlar, felsefî düşüncenin tam olarak ortaya çıkışından önce İslâm kültürünün filozoflarıdırlar. Onların ürünleri teknik kullanımıyla felsefe olarak adlandırılmamıştır fakat İslâm kültürünün en önemli ürünü ve felsefenin bir kesimiyle örtüşen yapısı düzleminde kelâm ilminin doğuşu, söz konusu içerik sayesinde olmuştur. Kelâm disiplinine bu anlamda, İslâm ilahiyat felsefesi denilebilir. İlahiyatın sadece metafizik alanla ilgili bir yapı olmadığının farkında olan 
Mu'tezilî âlimler, doymayan bir iştahla doğa, psikoloji, ahlak ve siyaset üzerinde de durmuşlardır. Onların kelâmî ıstılahları üretmeleri, söz konusu disiplinin gelişimini ve sonraki süreçte üzerine inşa edilen muazzam geleneğin de güçlenmesini sağlamıştır. Bu istılahlar arasında felsefenin kullandığı terimler ya da yakın anlama sahip kavramlar da bulunmaktadır. Bu yapıda adl ve tevhid, salah ve aslah, husn ve kubh gibi yeniden yapılandırılan içerikleriyle dinsel kavramların yanında kadîm, muhdes, mevcûd, madûm, cisim, ruh, cevher, araz, hareket, sükûn, kümûn ve tafra gibi felsefî konular da ele alınmıştır. Bu hususa dikkat çeken Medkur'un da ima ettiği nokta, felsefî kavramların kullanımı için uygun bir zeminin oluşumunda bu tür bir kelâm geleneğinin önemli yeri olduğudur. ${ }^{11}$

Diğer etkin faktör ise dile getirildiği gibi çevirmenlerdir. Bir ölçüde Emevî Dönemine kadar geri götürülebilecek olan çeviri hareketleri, yetkin felsefî eserlerin verilmesini ve felsefenin İslâm kültüründe yer edinmesini sağlamıştır. Bu süreçte bazı kavramlar, Arap diliyle ilintili olarak 1stılahîbir kullanım kazanmıştır. Söz gelimi hüviyet ve mahiyet en yaygın kullanımlardandır. Yine bazı kavramlar da Arapçalaştırılmış ya da doğrudan alınarak küçük değişiklerle kullanılmıştır. Örneğin Yunancadan kanun, cins, heyula, ustukus, namus, fantaysa, Süryaniceden mimer, sema'lkiyan, Farsçadan hendese bu tür sözcüklerdir. Bunlara ek olarak bazı eski sözcüklerin kullanıldığı ya da yeni terimlerin üretildiği de görülmektedir. Örneğin Kindî'nin vücut için eys kullanımı, bundan başka behîmiyye, melâikiyye, el-huve vb. sözcükler bu tür üretimlerdendir.

\section{Fârâbînnin Felsefî Düşünceleri}

\subsection{Fârâbî̀in Kısa Biyografisi}

Fârâbî̀nin geniş algı ve ilgi alanı kendinden önceki Müslüman filozofları kapsadığı gibi Bağdat Okulu'ndaki seleflerini de içermektedir. Öyle ki bu çaba ve ürünleri sonucunda Fârâbî, Aristoteles'ten sonra ikinci öğretmen lakabiyla büyük bir şeref ve şöhrete sahip olmuştur. Bu onur ve üne rağmen onun hayatı hakkında detaylı bir bilgiye sahip değiliz. Tarihçiler arasında Fârâbînnin adının Muhammed ve lakabının Ebû Nasr olduğu konusunda tartışma yoktur. Bununla birlikte İbn Ebî Usaybi'a (öl. 668/1269), İbn Hallikân (öl. 681/1282), Kıftî, Beyhakî (öl. 565/1169), İbnü'n-Nedîm (öl. 385/995) gibi yazarlar Fârâbî̀nin nesebi hakkında bazı farklıkları dile getirmişlerdir. Doğum yeri hakkında ise genel bir kanı bulunmaktadır. İbn Nedîm Fihrist'te ${ }^{12}$, Beyhakî Târîhu'l-hükemấ' ${ }^{13}{ }^{13}$, İbn Ebî Usaybi'a Uyûnu'l-enbâ' $\mathrm{da}^{14}$ ve İbn Hallikân Vefayât'inda ${ }^{15}$ Fârâbî̀nin doğum yeri olarak Fârâb'i göstermişlerdir. Fârâbî 872 yılında dünyaya gelmiştir. Tarihçiler onun hocaları olarak yalnızca Ebu Bişr Mettâ (öl. 328/940) ve Yuhanna b. Haylan'dan (öl. 860/920) söz etmektedirler. ${ }^{16}$

11 İbrahim Medkur, "el-Fârâbî ve'l-mustalahu'l-felsefî”, el-Fârâbî fi'z-zikra'l-elfiyyeti li vefâtihi, nşr. İbrahim Medkur (Kahire: el-Mektebetü'l-Arabiyyeti, 1983), 19.

12 Ebü'l-Ferec Muhammed bin Ebî Ya 'kūb İshâk en-Nedîm, Kitabu'l-fihrist, thk. Riza Teceddüd (Tahran: y.y., 1971), 321.

13 Zahiruddin el-Beyhakî, Tarih-u hukemai'l-̇̇slâm, thk. Muhammed Kürd Ali (Dımaşk: Matbaatu't-Terakki, 1946), 30.

14 İbn Ebi Useybi'a, Uyunu'l-enbâ fi tabakâti'l-etibbâ, thk. Nezir Riza (Beyrut: Dar-u Mektebeti'l-Hayat, Trs.), 603.

15 İbn Hallikân, Vefayâtu'l-a'yân, thk. İhsan Abbas (Beyrut: Daru Sadır, 1977), 156.

16 Mustafa Abdurrezzak, Feylosofu'l-Arap ve'l-muallim-i sâni (Kahire: Müessesat-1 Hindevi Li't-Talimi ve's-Sakafeti, 2012), 51. 
İbn Hallikân, Fârâbî hakkında "İslâm filozoflarının en büyüğ̈̈" kaydını geçtikten sonra başka hiç kimsenin onun ilmi seviyesine ulaşamadığını da eklemektedir. ${ }^{17}$ Bütün yetkinliğine rağmen Fârâbî, "sen mi yoksa Aristoteles mi daha iyi biliyorsunuz?" gibi bir soruya karşıllk verdiği, Aristoteles'in en büyük öğrencisi olma dileğine yönelik yanıt, onun tevazusuna bir işarettir. ${ }^{18}$

İbn Said (öl. 462/1070), özellikle Fârâbî'nin mantığa olan katkısını dile getirmekte ve Yuhanna b. Haylan ile mantık çalıştıktan sonra bu sahada bütün Müslüman düşünürleri aştı̆̆ını ifade etmektedir. Ona göre Fârâbî, seleflerinden söz gelimi Kindî gibi felsefecilerin bir noktaya kadar ele aldıkları mantık konularından kapalı noktaları aydınlatmış ve bunların ince detaylarını ortaya koymuştur. ${ }^{19}$

Fârâbî'nin kayıp eseri fi'z-Zuhuri'l-felsefe'de onun hayatı hakkında çeşitli bilgilerin bulunduğu aktarılır. Bunlara göre eserde, felsefenin klasik Yunan düşüncesinden Alexandrecı döneme ve buradan da İbrahim el-Mervezî (öl.307/ 920), Ebu Bişr Mettâ (öl. 328/940) ve Yuhanna İbn Haylan gibi büyük üstatların bulunduğu Bağdat'a intikali konu edilir. Buna göre mantık, Hıristiyan inancının prangalarınca zincirlenmiştir ve Fârâbî, mantıksal geleneğin içine düştüğü durumdan onu, ilk birkaç parçasından daha ileriye íkinci çözümlemeler (Kitâbu'l-Burhân) gibi Organon'un diğer parçalarına da taşıyarak kurtarmış, bir anlamda disiplini zincirlerinden azade etmiştir. ${ }^{20}$ Fârâbî'nin aynı zamanda oldukça yetenekli bir müzisyen olduğu da aktarılır. Kitabu'l-Mûsîka'l-kebîr gibi bu alanda önemli eserler vermiştir. İfadeye göre Fârâbî, Seyfuddevle'nin (öl. 944/967) huzurunda müzik aletini o kadar mahirane çalıyormuş ki bir "dinleti”sinde notalar değiştikçe dinleyiciler önce gözyaşlarına boğulmuşlar sonra gülmeye başlamışlar en sonunda da uykuya dalmışlardır. ${ }^{21}$

Genel çizgileriyle parlak kariyerinin başlangıcında Fârâbî, Bağdat Peripatetik düşün okuluna intisap etmiştir. Daha sonraki kariyerinde Suriye ve Mısır, Fârâbî için önemli duraklar olmuştur. Fârâbî, Şam bölgesinde Hamdânîler'in Halep kolunun kurucusu emir Seyfuddevle'nin himayesinde çalışmıştır ve 950/951 tarihinde vefat etmiştir. ${ }^{22}$

\subsection{Fârâbînnin Düşünce Tarihindeki İzleri}

Yakın bir döneme kadar Arap ve Batı dünyasında adının geçtiği pasajlar dışında neredeyse eserleri ve fikirleri itibariyle gün yüzüne tam anlamılla çımamış olan Fârâbî'yi belki de ilk kez değerini itiraf ve ilan ederek anan İbn Sînâ olmuştur. Ondan başka önemli sayılabilecek söz gelimi Gazzâlî (öl. 505/1111), İbn Bâcce ${ }^{23}$ (öl. 533/1139), İbn Tufeyl (öl. 581/1185) ve İbn Rüşd (öl. 595/1198) gibi düşünürler Fârâbî'den olumlu ya da olumsuz şekilde doğrudan bahsetmektedirler. Diğer taraftan

\footnotetext{
17 İbn Hallikân, Vefayâtu'l-a'yân, 153.

18 Hasan Hanefi, "el-Fârâbî şârihan Aristo”, el-Fârâbî fi'z-zikra'l-elfiyyeti li vefâtihi, nşr. İbrahim Medkur (Kahire: elMektebetü'l-Arabiyyeti, 1983), 67.

19 Ebü'l-Kāsım Said b. Ahmed b. Said el-Endülüsî, Tabakātü'l-ümem, nşr. Luis Şeyho el-Yesui (Beyrut: 1912 ), 53.

20 Majid Fakhy, Al-Fârâbî, Founder of Islamic Neoplatonism: His Life, Works and Influence (Oxford: One world Publications, 2002), 8.

21 İbn Hallikân, Vefayâtu'l-a'yân, 155.

22 İbn Hallikân, Vefayâtu'l-a'yân, 154-157.

23 Bkz. Muhammet Nasih Ece, İbn Bâcce Mantığı ve Fârâbî Bağlantıları (Konya: Çizgi Yayınları, 2021).
} 
Sühreverdî (öl. 587/1191), İbnü'l-Arabî (öl. 638/1240) İbn Seb'în (öl. 669/1270) gibi mutasavvıflar da Fârâbî'den etkilenmişlerdir. ${ }^{24}$

Fârâbî düşüncesinin bazı etkilerini Arap ya da Müslüman olmayan düşünürlerde de görmek mümkündür. Latince yazılan metinlerde ve Batı'da AlFârâbîus ya da Avennasar olarak anılan Fârâbî hakkında belki de en büyük övgü Aristotelesçi İbn Meymûn'dan (öl. 601/1204) gelmiştir. O, Samuel ben Tibbon'a (öl. 629/1232) yazdığı mektupta “Aristoteles'in düşünceleri Aphrodisias, Themistius ve İbn Rüşs gibi şârihler olmaksızın anlaşılamaz. Mantık çalışmaları da Fârâbî’nin şerhleri olmadan anlaşılamaz. Onun çalışmaları harikuladedir ve o büyük bir adamdır." ifadelerini kullanmıştır. ${ }^{25}$ Batıda 12. yüzyılın sonunda Arapça yazılımış pek çok tıp, çeşitli bilimler ve felsefe alanındaki çalışmalar Latinceye tercüme edilmiştir. Fârâbî’nin İhsâ’ sını Liber Al-Fârâbîi de Scientiis adıyla 1140 y1lında Latinceye ilk çeviren mütercim Gundissalinus (öl. 585/1190) ve ondan sonra da Gerard of Cremona'dır (öl. 582/1182). Gundissalinus bundan başka Episte on the Intellect (Akıl Üzerine Risale) adıyla da bir eseri Latinceye çevirmiştir. Bu çalışma Etienne Gilson (öl. 1978) tarafından Fransızcaya tercüme edilmiştir. Fârâbî̀nin Nikomachos'a Etik üzerine yazdığı eseri de Arapça kaynaklarda zikredilir fakat Arapça literatürde bulunmamaktadır. Bu çalışmaya Aquinas'ın hocası Albert the Great (öl. 682/1284) ve İbn Meymûn'da atıflar bulunmaktadır. Aynı şekilde fizik üzerine bir çalışma da zikredilmesine rağmen Arapça literatürde bulunmamaktadır. Bu eserin de Latin versiyonuna Roger Bacon (öl. 682/1284) ve Albert the Great gibi düşünürler atıfta bulunmuşlardır. Diğer bir çalışma da İkinci Çözümlemeler'in İslâm kültüründeki versiyonu Kitabu'l-Burhân'dır. Bu eserin kısa özeti ve uzun biçimi basılmıştır. ${ }^{26}$

\subsection{Fârâbî̀nin İslâm Felsefesindeki Yeri}

Onuncu yüzyılda Abbâsî Hanedanlığının yönetimindeki Bağdat, bölgesinde ve Avrupa'da bulunan bütün şehirlerden daha büyüktür ve çok kültürlü bir yapıya sahiptir. Bunun sonucu olarak şehir, düşünür ve bilim insanlarının da neredeyse buluşma noktası haline gelmiştir. Bu yer, felsefî akımlar arasında Bağdat Peripatetikleri diyebileceğimiz önemli bir ekole de ev sahipliği yapmıştır. Özellikle Aristoteles'in çalışmalarına odaklanmış ekol, Huneyn b. İshak (öl. 259/873) gibi çevirmenleri de barındırmaktadır. Aristoteles yorumcularının şerhlerini de ihmal etmeyen bu ekol mensupları, çevirilerinde kendi yorumlarını da ekleyerek Arapça felsefî literatürünün oluşmasında önemli bir misyon üstlenmişlerdir. Grubun en önemli simalarından Ebu Bişr Mettâ ve Yahyâ b. Adî (öl. 364/975), Aristoteles'in çeşitli eserlerini çevirdikleri gibi onun takipçilerinden Alexander ve Themistius'un yorumlarını da Arapçaya aktarmışlardır. Bu eserlerin kısmen Süryaniceden çevrilmiş olması, yukarıda değindiğimiz gibi, İslâm düşüncesinde bu dilin ve kültürel içeriklerinin de etkili olmasına yol açmıştır. Bu grubun ya da ekolün en önemli siması ise Fârâbî’dir. Fârâbî, söz konusu yapının en bilinen üyesidir. Bunun nedeni, onun felsefeye yaptığı katkılar, özellikle uzlaşım çabasında din ile felsefenin söz konusu olabilecek alanlarda olası ilişkilerini mahirane bir tarzda ortaya koymasıdır. Diğer neden, dile getirdiğimiz gibi onun, daha sonra İbn Sînâ’nın derinleştirdiği ve sistematik hale getirdiği mantık alanına yaptığı katkıdır. ${ }^{27}$

24 İbrahim Medkur, "el-Fârâbî ve'l-mustalahu'l-felsefî", 17.

25 Majid Fakhy, Al-Fârâbî, Founder of Islamic Neoplatonism: His Life, Works and Influence, 148.

26 Majid Fakhy, Al-Fârâbî, Founder of Islamic Neoplatonism: His Life, Works and Influence, 149.

27 Adamson, Philosophy in the Islamic World, 63. 
Fârâbî, Yunan felsefesiyle İslâm felsefesi arasında kurulan köprüde benzersiz bir konuma sahiptir. $\mathrm{Bu}$ konumun değeri, sözgelimi Aristoteles mantığı bağlamında, Latinceye önemli tercümeler yapan Boethius'tan on ikinci yüzyıl filozoflarından Abelard (öl. 535/1141)'a kadar geçen sürede onun kurucu etkisine sahip herhangi bir mantıkçının olmaması göz önünde bulundurulduğunda bile anlaşılacaktır. Daha önce Süryani gelenekte yer alan mantıkçılar, Porphyr'nin İsagoci'si, Aristoteles'e ait Kategoriler, Yorum Üzerine ve Birinci Çözümlemeler'in ilk bölümü dışında Hıristiyan inancına yönelik olumsuz içeriklerinden dolayı, daha doğru bir anlatımla konulan yasaklar nedeniyle, diğer çalışmalara ulaşım sağlayamamışlardır. ${ }^{28}$

Fârâbî, Süryani geleneğini ve Aristoteles'in bütün mantık çalışmalarını kapsayan eserleriyle seleflerinden ayrılmıştır. Fârâbî yalnızca mantık alanında kapsamlı bir felsefe ortaya koymamış aynı zamanda Kindî ve Razîyi de bir ölçüde aşacak şekilde kozmoloji ve metafizik disiplinleri düzleminde de sistematik düşünce üretmiştir. Bu açıdan Fârâbî, dile getirdiğimiz gibi İslâm felsefesinde ilk sistem kuran filozoftur. Bu sistemin bileşenleri, Eski Yunan ve Mısır düşüncelerini ve Yeni Platoncu öğeleri de içeren geniş bir yelpazeden oluşmuştur. Fârâbî̀nin siyaset, din ve ahlak felsefelerini de içeren sisteminin yapısı, Tanrı, yaratma, varlığın mahiyeti, kaderi vb. tartışmalı konularda yeni bir ruhu barındırmaktadır.

Müslüman filozoflar arasında bütüncül ve özgün bir felsefî sistemi de ilk kez ortaya koyan Fârâbî olmuştur. Daha önce anılması gereken simalar da bulunmaktadır. Söz gelimi Kindî, felsefede oldukça geniş bir kavram yelpazesini ele almış ve bunların analizine girişmiştir. Fakat onun çabası ele alınan kavramların belli bir hedef doğrultusunda kapsamlı bir bakış açısıyla bir arada değerlendirilmesi ve toplu bir fotoğrafını çekmeyi içermektedir. Yine Ebu Bekir er-Razî (öl. 925) de sistematik bir biçimde özellikle kozmoloji ve ilgili konuları ele almıştır. Eserlerinin çoğu kayıp olan filozofun, etik çalışmaları da önemli bir yere sahiptir. Fakat ifade ettiğimiz gibi Fârâbî, metafizik, kozmoloji, insan doğası, etik, siyaset gibi temel alanlarda, düşüncenin yeni filizlenmeye başladığı her mahfilde görülen olağan üstü bir arzu ve üstelik bütüncül bakış açısıyla, zamanı göz ününde bulundurulduğunda yetkin ürünler vermiştir.

\subsection{Fârâbînnin Felsefî Üslubu}

Yanıtlanması gereken bir soru bağlamında, kimi yazarlara göre, özelde Fârâbî’nin, genelde Müslümanların, diğer Yunan filozoflarından hatta Platon'dan daha çok Aristoteles'i şerh etmelerinin ya da onun felsefesini devam ettirmelerinin nedeni, bazı farkl1lıklara rağmen onun görüşlerinin, Müslümanların evren ve vahiy anlayışına uygun olmasıdır. Bu uygunluk nitelemesinin, benzerleri arasında evrilmiş bir biçeminin ortaya konulması sonucu kullanıldığını da not etmemiz gerekmektedir. Aristoteles'in bilgi ve mutluluk, genel-özel, nefs-beden, dindevlet, birey ve devlet vb. kavramlar arasında kurduğu ilişki, Müslümanlar için aşina oldukları ayrımları hatırlatmış, hatta belki de Tanrı-evren-insan bağlamında söz konusu olan ilişkinin Kur'an'da oldukça kapalı ve ağır bir eğretileme eşliğinde sunulmasının sonucu olarak, kendilerinin dolduramadıkları boşlukları doldurması nedeniyle onun felsefesi öne çımıştır. Diğer taraftan akıl yürütme düzleminde, çıkarım konusu, illet fikrinin önemsenmesi, aklın aynı zamanda kelâmcılar ve fukaha nezdinde naklin sıhhatinin garantisi olması gibi hususlar da etkili olmuştur. 
Bu etkilerin izdüşümünde biçimlenen gelenekte Fârâbî, sadece bir şârih değil aynı zamanda bir müelliftir de. Bu anlamda mantık üzerine yazdığı şerhler, çalışmalarının neredeyse yarısını teşkil etmektedir. Onun ortaya koyduğu bu çalışmalarda mantık, salt aklî ve nazarî içeriğe sahiptir ve bu yapı, kendi başına bazı soyut açıklamalar olmaktan daha ileri bir basamak olarak fikri planda başarılı bir şekilde biçimlendirilmiştir. Fârâbî'de hayat bulan yapı, sadece geleneksel Yunan motifleriyle örülmüş değildir. Buna tarihi seyirde, ilgili pek çok içerik de dâhil edilmiştir. Fârâbî'de mantık düşüncesi, sıklıkla dile getirdiğimiz gibi, öncelikli bir konuma sahiptir. Bu disiplinin arkasından ele alınan alanlar olarak siyaset, felsefe, Aristoteles'in diğer eserlerinin irdelenmesi, fizik, dil, geometri ve müzik gelmektedir. Fârâbî, çalışmalarında pragmatik bir sırayı dikkate almaktadır. O, programında müzik ile başlar sonra hikmete geçer, nazari içeriği çözümlemeden önce ameli ilimlere yönelir. Fârâbî, İbn Sînâ ve İbn Rüşd'den faklı olarak tıp gibi bazı bilimlerle de doğrudan uğraşmamıştır.

Fârâbî'nin, eserlerinde ortaya koyduğu üslup, değişkenlik arz etmektedir. Genel olarak "...hakkında söz/açıklama" biçiminde başlayan ve sistematik tarzda ortaya konulan ifadeler, doğrudan orijinal anlamın açılanması ve mananın düşünsel kökenlerinin ele alınmasına yöneliktir. Diğer yerlerde ise biçim, makaleler, muhtasar, ta‘lik ve risalelerde farklılık göstermektedir.

Fârâbî, büyük şerhlerini ta'lik yöntemine uygun yazmıştır ve bu eserlerinde o, önce orijinal eseri, sonra esere yönelik açılamalarını ortaya koyar. Bu tarz, söz gelimi İbn Rüşd gibi filozofları da etkilemiştir. Bu biçim, kaba bir taklit ya da onları kutsama biçiminde değil, bu metinlerin anlaşılmasına yönelik bir çaba ve mevcut birikime dâhil etme gayretini içeren saygın bir yaklaşımdır. Fârâbî, diğer şârihlerin düşüncelerini de ele alır ve onların doğru veya yanlış yönlerini ortaya koyar. Fârâbî, metnin içerdiği kavramsal dizgede menâtı ortaya koyar, bunları dikkatli bir biçimde ayrıştırır. Bu çerçevede kavramın yeri, kullanım biçimi ve buna bağlı olarak çeşitli çıtııları da incelikle okuyucuya arz edilir. ${ }^{29}$

Fârâbî, Aristoteles'i tek başına değil çeşitli otoritelerle birlikte, özellikle Platon'la beraber, kapsayıcı bir yaklaşımla ele almıştır. Onun bu yaklaşımı el-Cem beyne re'yeyi'l-hakîmeyn adlı eserinde açıkça nedenleriyle birlikte ortaya konulur. Fârâbî, felsefenin tek bir hakikati barındırdığını, bütün farklılıkların ve hataların, yapının yanlış anlaşılmasından kaynakladığını düşünmektedir. Fârâbî’nin söz konusu eseri yazmasının nedeni, çağdaşlarından çoğunun sahip oldukları, Aristoteles'in ve Platon'un felsefî anlamda önemli görülen, evrenin kıdemi ya da hudûsu, yaratıcının varlığı, ruhun ve aklın doğası, doğru ya da yanlış eylemle ilgili karşıt; ahlak, siyaset hatta mantık konularında farklı görüşleri bulunduğuna yönelik kanılarını değiştirmektedir. ${ }^{30}$

Fârâbînnin çalışmaları en geniş anlamda üç kategoriye ayrılır. Bunlardan ilki, giriş amacıyla yazılanlardır. Giriş çalışmaları, ahlak, mantık, Platon ile Aristoteles felsefelerinin temellerini tanıtma ve yorumlamaya yöneliktir. Ahlak bağlamında Mutluluğun Kazanılması, Aristo ve Platon felsefesi, mantık düzleminde Kategoriler vb. ile İlimlerin Sayımı, onun öne çıkan eserleridir. İkinci

29 Hasan Hanefî, “el-Fârâbî şârihan Aristo”, 71.

30 Hasan Hanefi, “el-Fârâbî şârihan Aristo”, 98. 
kategori, Nikomakhos'a Etik ve Organon külliyatı üzerine yazılmışşerhlerden oluşmaktadır. Üçüncü kategori ise Fârâbî’nin kendi özgün felsefesini yansıtan ve aslında senkretik bir karakterde olan eserleri içermektedir. Erdemli şehir bu kategori için dikkat çekici bir örnektir.

Fârâbî̀nin ortaya koyduğu külliyat, kendinden önce söz gelimi Aleksandrecı okulun yaptığı gibi, kültürel açıdan çeşitli düzeylerde kendi kültürüne ve felsefe geleneğine uygun şekilde Aristotelesçi düşünceye yeni bir form vererek üretilen yorumları içerir. Bu yapı felsefenin hemen hemen bütün ilgi sahalarını da barındırmaktadır.

Fârâbî, genel anlamda, geç Antik dönemin felsefî öğretim programını kendi yorumuyla ortaya koymuştur. Fârâbînnin kendine özgü programının özelde ima ettiği yol, mantıkla başlanıp sonra fiziğe ve metafiziğe geçilmesi biçiminde kurgulanmıştır. Sonra ahlak ve siyaset felsefesine bakılmalıdır. íkinci çözümlemeler bu program için önemlidir. Burada Fârâbî, felsefî bilimlerin birbirlerinin üzerine nasıl inşa edileceğine dair açıklamalarda bulunur. Buna göre ilkeleri veren daha yüksek bilimler, diğerlerinin üzerlerine bina edileceği temelleri sağlar. Örneğin geometri, optik bilimi için ilkeleri sağlar. Buna göre araştırmacı, aynalardaki yansıma gibi şeyleri çalışabilmek için geometriye ihtiyaç duymaktadır. Oysa geometri bilginlerinin optik çalışmalarına gerek bulunmadığından dolayı bunun aksi doğru değildir. ${ }^{31}$ Fârâbî̀ye göre sonuçta bütün insan bilgisi, söz konusu şekilde bilimlerin bir hiyerarşisine tabidir. Bununla birlikte ona göre metafizik ya da ilk felsefe diğer bütün bilimlerin ihtiyaç duyduğu ilkeleri vermektedir. ${ }^{32}$ Onun bu tür bir sıralamaya üst noktada mantık ya da fizik yerine metafizikle başlamamasının nedeni Aristoteles'in işaret ettiği gibi, ilksel olan genellikle kendine özgü olarak ilksel olanla aynı değildir. ${ }^{33}$ Örneğin Tanrı, nedenler arasında ilk sıradadır fakat $\mathrm{O}$, bizim künhüne vakıf olabileceğimiz bir ilk neden değildir ya da kolaylıkla anlayabileceğimiz bir ilk değildir. Aksine insan, araştırmaya kendi çevresine ait fiziksel evrendeki nesnelerden başlar, bunları anlar daha sonra daha temel olan örneğin Tanrı gibi ilkeleri keşfetmeye doğru adım atar. ${ }^{34}$ Fârâbî, ilk felsefenin yalın bir şekilde her şeyin ilk nedeni olarak Tanrı'yı ele alan bir alan olduğunu kabul etmemektedir. Aristoteles'in Metafizik'ini irdelediği eserinde Fârâbî, insanların ilk felsefenin teolojiden başka bir şey olmadığına yönelik yargıdan dolayı Metafizik adlı eser hakkında kafa karışıklığı yaşadıklarını dile getirmektedir.

Fârâbî̀ye göre de ifade ettiğimiz gibi ilk felsefe, bilimler arasında ayrıcalıklı bir yere sahiptir ve Tanrı'nın ilk neden olmasından dolayı teolojiyi de içermektedir fakat daha özel anlamda Metafizik'te irdelendiği biçimiyle önemli ilkeleri de ortaya koymaktadır. ${ }^{35}$ Fârâbî'nin öğretisinde önemli bir yer tutan husus, bilinen şeylerden hareketle ilk ilkelere ulaşmak, potansiyel olarak bizim için mümkün bütün bilimleri elde etmektir. Bunun sonucunda elde edilecek değer ise insan türü için nihai mutluluktur. ${ }^{36}$ Elbette bunun için Fârâbî, evrenin yapısı ve onun sakini olarak insanın üretimi olan siyaset felsefesi üzerine yoğunlaşmıştır. Fârâbî aşina olduğumuz şeylerden

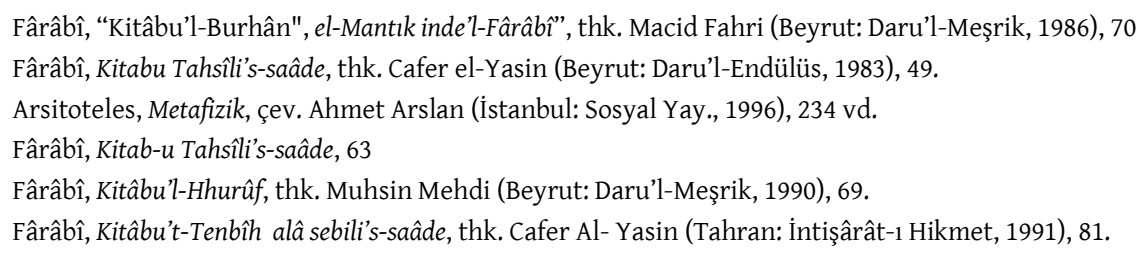


değil gerçekten ilksel olanın ne olduğu sorunundan yola çıkar. Fârâbî bu yolda, Aristoteles'in görüşleriyle Yeni Platoncu kurguyu kaynaştırma çabasına girişmiştir.

\subsection{Fârâbî̀nin Tanrı ve Âlem Görüşü}

Fârâbî, felsefesinin 'bel kemiği' biçiminde bir istiare ile betimlenebilecek olan metafizik örgüsünün en tepesine, Yeni Platoncu akımın en önemli temsilcilerinden Atinalı Proclus'tan (öl. 485) mülhem, ilk varlık anlamına gelen el-Evvel nitelemesinde bulunarak Tanrı'yı yerleștirmiştir. Fakat bu zirve noktada konumlandırılan Fârâbî'nin el-Evvel'i, Plotinus'un (öl. 270) Bir'inden ve Proclus'un el-Evvel ya da İlk'inden belli açılardan farklıdır. Bu anlamda Tanrı, her şeyin üstünde gelen konumu doğrultusunda akıl, âkil ve mâkul olarak kendini düşünen bir düşünce niteliğiyle, diğer her şeyin de kendisinden sâdır olması yönüyle, bir bakıma Aristoteles'in hareket etmeyen hareket ettiricisiyle özdeştir. Fârâbî'de Tanrı saf akıldır ve âlemdeki bütün varlıksal hareketin ilk nedenidir. ${ }^{37}$ Fârâbî̀ye göre 0 , sadece en yüksek ferdî akıl değil aynı zamanda göksel varlıkların temel hareketlerini de sağlayan tek, biricik güçtür. Ona göre, göksel kürelerin kendilerine özgü akılları da vardır. ${ }^{38}$ Bu noktada Yeni Platoncu bir etki ile Fârâbî, diğer akılların ve kürelerin bir tür feyezan biçiminde Tanrı'dan sudûr ettiğini savunur. ${ }^{39}$ Buna göre Tanrı, göksel kürelerin en dış noktasıyla ilgisi bulunan ilk akl1, sudûr yoluyla harekete geçirir. Plotinus'tan mülhem şekilde akıl, ilk ilke olan ve en yalın şekilde Bir olarak betimlenenden çıkar. Fârâbî, bu noktada bazı değişikliklere gitmiş görünmektedir. Ona göre göksel ya da kutsal akıllar, tek tek birbiri ardınca ilerleyen bir sıra takip etmektedirler. Bunlardan her biri, sonra gelene hareket sağlar ve bu dizinin üstündeki ilk akıl ise Tanrı'dan sâdır olur. Bütün akıllar, göksel kürelerle iç içe olacak şekilde bir ilişki sergilerler. Bunu bir benzetmeyle, birbiri içine geçmiş şeffaf cam toplar ya da şeffaf matruşkalar olarak ortaya koyabiliriz. Onların hareketleri, üzerlerine yaslanmış ve "dünyamızın etrafında dönen" görünebilir olan gezegenler yoluyla bize malum olur. Bu dizi, dünyamızın göklerin altında, mevcut yerinde ve yapısında bulunmasını sağlayan, en alttaki akla kadar devam etmektedir.

Fârâbînnin dizgesinde, bütün ihtişamına rağmen Tanrı yerine en alt akıl, bazı noktalardan belki de üzerinde durulmayı hak eden en önemli varlıktır. Onun işlevi, Fârâbînnin kozmoloji ve bilgi kuramına göre benzersiz ve oldukça değerlidir. En aşağı akıl böyle bir rolü üstlenir çünkü o, Plotinus'un tek aklından farklı şekilde, dünyamızda akledilebilir formları örneklendirebilecek biçimde ve evrensel ölçekte, düşünme kapasitesine sahiptir. Bu formların örneği, bütün mümkün bilgiyi içeren bir kütüphane olarak verilebilir. Bu örnek oldukça yerindedir fakat ince bir detay daha vardır. O, düşünen bir akıl olması nedeniyle, kütüphane ile karşılaştırdığımızda, onun kendi kitaplarını okuyan bir kütüphane olduğunu da göz önünde bulundurmalıyız. Bu aklın kozmolojik işlevi, dört ana maddeden yapılmış şeyleri, yeryüzünde kendi konumlarına yerleştirmektir. Dört element birleşir ve en alttaki göksel akıldan kaynaklanan form giydirilerek yerdeki varlıklar oluşur, şekillenir. Bu akıl, İslâm felsefesinde form verici anlamında, Latince'de Dator Formarum biçiminde ifade edilen, Vahibu's-Suver olarak adlandırılmıştır. Fârâbî'de Faal Akıl olarak da adlandırılan bu güç, insan aklını aktif hale getirmekte, bizim için mümkünlere ait bilginin

Fârâbî, Risâle fi'l-Akl, nşr. Maurice Bouyges (Beyrut: Daru'l-Meşrik, 1983), 35.

Fârâbî, Kitâbu Ârẩi ehli'l-medîneti'l-fâzıla, nşr. Elbir Nasri Nadir (Beyrut: Daru'l-Meşrik, 1985), 61.

Fârâbî, Kitâbu Ârẩi ehli'l-medîneti'l-fâzıla, 69. 
kapılarını açmaktadır. Bu kuramdaki Faal Akıl, aynı zamanda, Fârâbî için peygamberlik kavramını anlamada kilit rol üstlenmektedir. Ona göre peygamberin zihni, bütünüyle Faal Akll tarafından yapılandırılmıştır. Bu anlayış, dünyanın tasarımını ve insanlığa rehberlik eden peygamberin aklını aynı kaynağa nispet edilmesini ima ederek bilimsel bilgi, din, toplum, ahlak ve siyaset düşüncesi hakkında önemli ipuçları vermektedir. ${ }^{40}$

$\mathrm{Bu}$ düzlemde yukarıda dile getirdiğimiz sistemi detaylandırabiliriz. Fârâbînnin kozmolojisi, Aristotelesçi nedenselliğin metafiziksel boyutunun, bir yönüyle Batlamyus'un astronomi anlayışına dayanan, Yeni Platoncu sudûr öğretisinin geliştirilmiş biçiminin oluşturduğu düşüncelerin ve İslâmî anlayışın bileşiminden oluşmuştur. Fârâbî, söz konusu bütüncül yaklaşımında, öncelikle altı ilke/mebâdi öne sürmektedir. Bunlar; ilk neden, bundan sonraki gayr1 cismani olan ikincil nedenler ya da akıllar, ay altı dünyasını yöneten Faal Akıl, ruh, form ve maddedir. ${ }^{41}$ Sudûr öğretisi çerçevesinde hiyerarşik bir sıralama ile anlatılan yapıda, ilk nedenden doğan akıllara ve bu dizinin en altında bulunan öğelere kadar giden bir sıralama ortaya konulur. İlk neden, açıkça her şeyin ortaya çıkışından sorumlu olan, hareket etmeyen hareket ettirici Tanrı'dır. Tanrı'nın dışındaki yakın nedenler, ilk nedene olan bir arzu sonucu ortaya çıkıp yönelimde bulunurlar. Bu akıllar, ruh ve cisimler, dokuz göksel akıl küresi üzerinden ortaya çıkmaktadırlar. İlk akıl, evreni çevreleyen ilk sema ile ilişkilidir. İkinci akıl, kendi yörüngelerinde bulunan yıldızlar semasıyla ilişkilidir. Böylece her bir akıl Fârâbî̀nin zamanında bilinen göksel cisimlerle ilintilendirilir. Bunlar Satürn, Jüpiter, Mars, Güneş, Venüs, Merkür ve Ay'dır. Son akıl ise dile getirildiği gibi Fârâbî̀nin deyimiyle Faal Akll'dır ve dünyada ortaya çıkan her türlü oluş ve bozuluştan (el-kevn ve'l-fesâd) sorumludur. ${ }^{42}$

Fârâbî̀nin sistemi, oldukça karmaşı görünmekle birlikte dönemine göre, kendinden önce ortaya konulan Aristotelesçi öğretiler ve Batlamyusçu astronomi anlayışı gibi sistemlerin bütününü kapsamakla kalmaz, bunları daha dizgesel bir biçimde yeniden tasarlar. Bu tasarım, Tanrı, insan, metafizik varlıklar ve evren ilişkisinin rasyonel bir potada nasıl telif edilebileceğinin de mükemmel bir örneğini sunmaktadır. Fârâbî’nin, ilk nedeni içeren dizgesi, başarılı şekilde metafizik ve epistemoloji anlayışının bir arada açıklandığı yapıdır.

Fârâbî̀nin ortaya koyduğu açıklama, insan aklının diyalektik bir bölümleme ve tanım süreçleriyle doğrudan bilme olanağının bulunmadığı ilk neden ilkesini kanıtlamaya ya da anlatmaya odaklanmıştır. Bu açıklamada ayrıca daha da ileri bir adım olarak bileşenlerin, mantıksal bir çözümleme yoluyla varlığa dair ontolojik yapısının ortaya konulması söz konusudur. Bu ontik yapıyı tanımlama ameliyesi, şeylerin bilfiil cevhersel bileşenlerini de içermektedir. Bu tavır, Porphyry'nin İsagoci'sinin yöntemini ve metafizik bağlamda Aristotelesçi kategorilerin oturduğu düzlem hakkındaki uzun bir tarihi, yeni bir yaklaşımla sergilemektedir. Fârâbînnin varlık ve akıllara dair sudûr içerikli açıklama yapısı, cins ve türlere bölümlenmiş biçimde ortaya konulan bileşenlerin de açı bir çözümlenmesidir. Bu açıklama, ilk nedenin doğasının yanında, bileşenler aracılığıyla cevherlerin sahip oldukları temel özellikleri ve onların içerdikleri çeşitli süreçleri

${ }_{40} \quad$ Bkz. Fârâbî, Kitâbu Ârẩi ehli'l-medînetil'-fâzıla; Adamson, Philosophy in the Islamic World, 69.

${ }^{41}$ Fârâbî, Kitâbu Ârâ’i ehli'l-medîneti'l-fâzıla, 63.

42 Fârâbî, Kitâbu Ârẩi ehli'l-medîneti'l-fâzıla, 61. 
açığa çıkartır. Örneğin her küreye ait ruh aynı zamanda onun formudur. ${ }^{43}$ Ruh ve küre ya da ruhun bütünleștiği özne, bütünüyle birbirlerinden kopuk değildir. Tıpkı bir bal mumunun, içerisine batırılan şeyin bütün yüzeylerine yayılıp onun biçimini alması, suretin de bal mumuna bürünmesi ve sonunda ayrımın oradan kalkması, bu tür bir yapıyı betimlemektedir.

\subsection{Fârâbînnin İnsan ve Bilgi Anlayışı}

Psikoloji ve Ruh anlayışı bağlamında Fârâbî̀ye göre insanın zâtını oluşturan birkaç temel nitelik vardır. Duyuma ilişkin, nesneye yönelik arzu ya da nefret içerikli iştah, cisimlerin duyumuna dair algı, duyumsal nesnelerin kavramsallaştırılması ve onlar üzerinde konuşmayı sağlayan kuvve-i hayaliye, bunlardandır. ${ }^{44}$ Bitki, hayvan ve insanlar bağlamında çeşitli derecelerde bulunan ruh, insan söz konusu olduğunda, ekletme yeteneğine hizmet eder ve onun diğerlerini de etkileme pozisyonunu ortaya çıkartır. Bu yeti, akıl sahibi ruhtur ve bedenin ölümünden sonra da belirli koşullara bağlı olarak hayatta kalacaktır. Ortaya konulan yapı içerisinde bütün bileşenler, teolojik bir yorum bağlamında irdelenir ve bu açıdan onlardan her birinin, mükemmellik ülküsü çerçevesinde, ilk nedene benzeme amacıyla var oldukları savunulur. Akıllı varlıkların amacı, fiili ve sürekli bir akletme faaliyetidir ve insanın da bu süreçteki hedefi, belirttiğimiz gibi nihai mutluluktur. Bu sonsuz yolda mutluluk, dile getirildiği gibi, sürekli ve fiili akletme eyleminden geçmektedir. İnsan, akletme yetisine doğuştan bütün hatlarıyla sahip değildir ve bu nedenle onun, anılan niteliği geliştirmesi gerekmektedir. Bu akletme edimi, her insan için aynı seviyede de gerçekleşmez. İnsan aklı, maddi düzeye ait olduğu için sadece belirli bir potansiyeli barındııır. Bunun ilk basamağı, bilinç ve son basamağı da kapasitesi elverdiği ölçüde mükemmelleşmektir. ${ }^{45}$

İbn Ebi Usaybia ve Kıftînnin aktardıklarına göre Fârâbî, 17 şerh, 20 kitap, 25 risale kaleme almıştır. ${ }^{46}$ $\mathrm{Bu}$ çalışmalar mantık, genel felsefe, matematik, kimya, astronomi ve müzik gibi farklı pek çok alanı kapsamaktadır. Fârâbînin, konuları geniş bir perspektiften fakat oldukça dakik bir bakış açısıyla ele aldığını söyleyebiliriz. Örneğin genel anlamda mantık üzerine yazılmış çalışmaların satır aralarında teoloji başta olmak üzere felsefenin çeşitli sorunlarına da temas edilmektedir. Onun elimizde bulanan çalışmalarından, söz gelimi şerhu'l-ibâre/Yorum Üzerine şerhi, Fârâbî̀nin Aristoteles'ten devraldığı bilgi ve mantık felsefesine dair bazı sorunları işlediği eseridir. Fârâbînnin belirttiği gibi bu eserde Aristoteles'in amac1, temel yargılara ait kesinlik ifade eden yapıları sentaks (söz dizimi/nahiv) bağlamında incelemektir. Beş bölümden oluşan şerhte, ilk başlık altında yargı bildiren ifadelerin (el-kavlu'l-câzim) oluşturulmasında isim, kelime ve onların parçaları ele alınır. İkinci bölümde, mütekâbil (karşıtlık halinde olan) kavramlar ele alınırken üçüncü bölümde yüklemli kategorik yargılar incelenir. Dördüncü bölüm benzer şekilde karşıtlık içinde olan yüklemli kategorik yargılara ayrılmıştır. Son bölümde ise karşıtlık içeren kavramların çeşitli yapılar bağlamında ortaya çıkan görünümleri arasındaki ayrımlar incelenmektedir. ${ }^{47}$ Söz konusu eserde dakik bir irdelenmeyi hak eden konulardan biri, aynı zamanda, Fârâbî’nin mantık çalışmalarının kapsamını göstermesi bakımından anılmayı hak eden, determinizm sorununa

43 David C. Reisman, "Al-Fârâbî and the Philosophical Curriculum”, The Cambridge Companion to Arabic Philosophy, ed. Peter Adamson ve Richard C. Taylor (England: Cambridge University Press, 2005), 52-72.

44 Fârâbî, Kitâbu Ârâ’i ehli'l-medineti'l-fâzıla, 68.

45 Fârâbî, Kitâbu Âr'âi ehli'l-medineti'l-fâzıla, 105.

46 İbn Ebi Useybi'a, Uyunu'l-enbâ fi tabakāti'l-etibbâ, 603; Kıftî, İhbâru'l-ulemâ bi ahbâri'l-hukemâ, 210.

47 Fârâbî, "Kitâbu'l-i̇bâre", el-Mantık inde'l-Fârâbî, thk. Refik el-Acem (Beyrut: Daru'l-Meşrik, 1985), 133-163. 
ilişkin olan ve sonuçta mantık ilklerini de ilgilendiren deniz-savaşı hakkındaki argümandır. Fârâbî̀ye göre her ne kadar Aristoteles, burada mantık açısından ele alsa da determinizm, fizik ya da metafizik alanda da tartışılması gereken bir kavramdır. Aristoteles, gelecek hakkında şimdiye dair bir önermenin doğruluğunun, geleceğe ilişkin bir zorunluluğu doğurduğunu kabul etmemektedir. ${ }^{48}$ Ona göre gelecek hakkındaki bir yargı zorunlu değildir. Bu, oldukça açıktır ve böyle bir düşünce Fârâbî̀ye göre sadece bazı itibarı olmayan kişilerce reddedilmiştir. Fârâbînnin eserinde Aristoteles'in, yalnızca önermelerin doğruluğu hakkında bir konu olarak alınan deterministik argümanı, daha geniş bir çerçevede ortaya konulmuştur. Buna göre, gelecek hakkındaki önermeler doğru ya da yanlış olarak nitelendirilemez aksi halde deterministik çıkarımların saçma sonuçlarıyla karşılarız. Elbette Fârâbî, Tanrı'nın geleceği bildiğine yönelik yargıya olumlu yaklaşanlar nazarında böyle bir çıarımın sorun teşkil ettiğini kabul etmektedir. Nitekim geleceğe dair söz gelimi bir deniz savaşı hakkında mevcut zamanda herhangi bir gerçeklik dile getirilemiyorsa Tanrı, geçmiş bir zamanda geleceği nasıl doğru biçimde bilebilir? Fârâbînnin böylesi bir Tanrı bilgisini kabul ettiğine yönelik açık bulgular yoktur. Fakat Fârâbî̀nin konu bağlamında felsefî açıdan önemli kabul edilebilecek kendine has ikinci bir çözüm önerisi bulunmaktadır. Fârâbîye göre yalnızca, söz konusu edilen içeriğin vukuu nedeniyle gelecekteki olayları zorunlu yaptığı düşünülen mevcut doğrular, onları öngören şimdiye dair doğru önermelerle ima edilebilir. ${ }^{49}$ Diğer bir anlatımla, "yarın bir deniz savaşı olacak" dediğimizde bu öngörü, yarın bir deniz savaşı olacağını ifade eder. Fakat referans ve olay arasında zorunlu bir bağlantı bulunsa da ifadenin doğruluğu, kendi başına zorunlu değildir. Üstelik "yarın bir deniz savaşı olacak" ifadesi, bütünüyle doğru olsa da mevcut anda, olası olarak doğrudur. Eğer ifade doğruysa bu, yalnızca olası olarak deniz savaşının olacağını ima eder, zorunlu olarak değil. Bunun aksine, gelecekte iki ve ikinin toplamı dört eder denmiş olsaydı, ima zorunlu olduğu için bu, kesinlikle şimdi de zorunlu bir doğru olurdu. Oysa Tanrı, önceki bir zamanda, işler farklı şekilde gelişse bile gerçekte deniz savaşının olacağını, anılan tarzda bilme durumundadır. Fârâbî'nin mantık hakkında ortaya koyduğu mezkûr konuyla ilgili önemli çalışmalar, Aristoteles epistemolojisiyle de yakından ilgili olan, İkinci Çözümlemeler/Kitâbu'l-Burhân ve diğer küçük eseri Şeraitu'l-yakin adlı eserlerdir. Bu çalışmalarda Fârâbî, Aristoteles tarafından ortaya konulan kesin bilgiye dair içeriği, sistematik şekilde ele alıp işlemektedir. Fârâbî̀ye göre, yalnızca inandığımız içerik, zorunlu ve sürekli, sabit doğru olduğu zaman, kendimizi kesinliğe ulaşmış olarak kabul edebiliriz. ${ }^{50}$ Öyleyse açıktır ki deniz savaşı gibi gelecek hakkındaki olaylar bağlamında nihai bir kesinlik söz konusu değildir. Bu tür yargılar, sabit olmadıklarına göre hiçbir şekilde zorunlu da değillerdir. Bu savlar bile örneğin Adamson'a göre Fârâbî̉nin, Tanrı'nın geleceği bilmesi noktasında, kesin bir kanaate varamadığını imlemektedir. Eğer gelecek olaylar, bu tür bir niteliğin parçası değilse, herhangi bir kişi onu kesinlik ölçütünde bir bilgiyle bilebilir ve öyleyse Tanrı bilgisi, bütünüyle doğası gereği bu bağlamda, kesinlik arz edebilecektir. Söz konusu yaklaşıma karşıt bir durumda gelecekteki olaylar, Tanrı bilgisinin bir parçası değildir. ${ }^{1}$

48 Aristoteles, "De Interpretatione", Complete Works (Aristotle), ed. Jonathan Barnes (New Jersey: Princeton University Press, 1991), 7.

49 Fârâbî, "Kitâbu'l-i̇bâre", 157 vd.

50 Fârâbî, “Kitâbu'l-Burhân", 20.

51 Bkz. Peter Adamson, Philosophy in the Islamic World, $46 \mathrm{vd}$. 
Kitâbu'l-Hurûfta Fârâbî, kesinlik bağlamında, Organon külliyatının işaret ettiği içeriğe, çeşitli yönlerden açıklık getirir. O, temelde burhânî/kanıtlamacı felsefenin diyalektik, sofistik ya da diğer mantıksal çıkarımı içeren yöntemlerden ayrıştığını, bunlardan da değerli olduğunu dile getirmiştir. ${ }^{52}$ Ona göre, mille olarak ifade edilebilecek dinin yükselişi, felsefenin ortaya çıkışını takip etmiştir. Bununla birlikte Fârâbî'ye göre dinsel söylem, felsefenin burhâna dayanan ve nazarî karakterdeki yapısına karşılık, halkın aşina olduğu ve kolaylıkla kabul edebileceği, cedelî (diyalektik) yönteme dayanan, imgesel bir yapıya sahiptir. Dinin hizmetinde olan kelâm sanat 1 ise buna benzer içerikleri kullanmaktadır ve genel anlayışa göre, cedele yakın, söz gelimi hatâb̂̂ (retorik) dayanak, kanıtlamaların değerini ortaya koyan çizelgede, diyalektik içerikten bile daha aşağıda kategorize edilen, retorik kanıtlar sınıfına aittir. Fârâbî'ye göre bir kelâmcının yaptığı şey, dinsel ilkeleri, burhâna dayalı kesin kanıtlamalar yerine, cedelî ve hatâbî kanitlar yoluyla da olsa, her ne pahasına olursa olsun savunmaktır..$^{53}$

Yukarıda ilmek ilmek işlenen yapının genel resmi, onların ilimler tasnifinde yer aldıkları konumda, ince hatlarla çizilmiştir. İlmu'l-lisan, ìhsâ'da beş bölümde incelenen, ortaya konulan sınıflandırmanın ilk bilimidir. Bu bilimde anlama/mefhuma işaret eden sözcükler ve bunların iletişim evreninde ya da kavramsal ekosistemde işe yaramasını sağlayan gramer, genel anlamda dilsel kanunlar ele alınır. Mantık, matematik, metafizik ve fizik ile son sırada sayılan, birbiriyle bağlantılı şekilde ele alınan ahlak, siyaset, fikıh ve kelâm, diğer bilimlerdir. ${ }^{54}$ Tasnif edilen söz konusu disiplinler de kendi içinde alt dallara ayrılmaktadır. Fârâbînnin tasnifi, Aristoteles'in sınıflandırmasından farklılık göstermektedir. Dile getirdiğimiz program dâhilinde çeşitli disiplinleri tasnifinde zikreden Fârâbî için mantıktan önce dil bilimlerinin, sonra fizik ve metafiziğin (ilahiyat) olması kurgusunun, mantıksal ve pratik bir amaca uygun olarak ortaya konulduğunu göstermektedir. Mantık için dilsel yapılar, fizik ve ilahiyat için de onları anlamaya geçiş zemini olacak mantık, genel anlamda tabiat bilimleri, doğal bir sıralama olarak belirmektedir. Bütün bunların arkasından dini bilimlerin önemli alanları olan kelâm ve fikhın sayılması, bunların da ahlak ve siyaset gibi iki önemli konuya iliștirilmesi, Fârâbî’nin düşün sisteminin nihai amaçlarını ve yöntemini gözler önüne sermektedir. Başlangıçtan beri felsefe ile dini uzlaştırmaya çalışan Fârâbî, dinsel öğretilerin ahlak ve siyasetle bağlantılı olduğunu, bunların da ilahiyatın şemsiyesi altında anlamlı olabileceğini ima eder. îlahiyatı anlamanın yolu ise daha önce dile getirilen bilimlerdir. Böylece o, Ebu Bişr Mettâ b. Yunus'un, Sirafî ile girdiği tartışmada tam olarak ifade edemediği hususu, bu tasnif yoluyla ortaya koymaktadır. Dil, tek başına anlamın kaynağı olamayacağı gibi diğer alanların dışlandığı, yalnızca kendilerine dayanılan dini bilimler de şeriatın insanlardan istediklerini onlara sağlamaya uygun değildir. Bu noktada Fârâbî’nin din ve felsefenin uzlaşmasına yönelik düşünceleri, kendi mantıksal dizgesinde doğal bir sonuç olarak ortaya çıkmaktadır. ${ }^{55}$

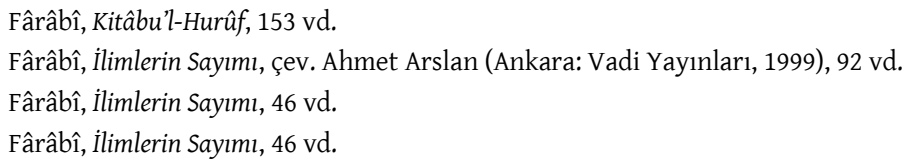




\section{Fârâbînin Mantık Anlayışı}

\subsection{Mant1k Nedir?}

Yukarıda belirli açılardan konumu ifade dilen mantık Fârâbî'ye göre, insan düşüncesini hata yapılması olası durumlarda, doğru olana yönlendirme amacını gütmektedir. Mantık, aklın çıkarımda bulunma yetisi/aracı olarak kullanıldığı bütün konularda, söz konusu olabilecek hatalara düşülmemesi için gerekli olan noktaları öğreten bir disiplindir. Fârâbî'ye göre teorik ve pratik (ameli ve nazari) bütün ilimlerde mantık, yerinde kullanılması halinde, kesin ve doğru bilgiye ulaşılmada en önemli dayanaktır. Bu anlamda hangi ilim olursa olsun, doğru sonuçlara ulaşılmak isteniyorsa, mantık bilimine ya da sanatına ihtiyaç bulunmaktadır. Fârâbî'nin ifadesine göre mantık, nutk sözcüğünden müştaktır/türetilmiştir. Eskilerin (kudemanın) kabulüne göre bu sözcük, şu üç şeye delalet etmektedir: İnsanın, akledilirleri (ma'kul, kavram) anlamada kendisine dayandığ 1 bir kuvvet olması, ilk anlamdır. Bu kuvvete dayanarak insan, ilimleri ve sanatları elde eder, eylemler söz konusu olduğunda güzel ve çirkin olanı ayrıştırır. İkincisi, insanın düşünme noktasında, zihninde oluşan kavramlardır ve buna da iç konuşma adı verilmiştir. Üçüncüsü ise zihinde bulunan içeriği dışa vurmaktır ve buna da dış konuşma adı verilmiştir. Fârâbî'ye göre dış konuşma, dil ve onun işlevinden ibaret bir bölümdür. ${ }^{56} \mathrm{Bu}$ bölümlemenin imlediği anlama göre içdış nutk ve idrak gücü birleşince mantık sanatı için bütün şartlar sağlanmış olmaktadır. Dil bilgisi ya da gramerin, herhangi bir dil için önemi veya işlevsellik noktasındaki yeri neyse, mantık sanatının da akıl için yeri odur. Dil bilgisinin, anlaşmak zorunda olan bir milletin dilini, gerçek bir dil yapması gibi mantık da akla dayalı olan konularda ortaya konulan sonuçların doğruluğunu garanti altına aldığı için düşünceyi ve çıtıllarını doğruya yönlendirerek onu deyim yerindeyse gerçek/doğru bir düşünce yapar. Dil bilgisi, doğru konuşmayı; mantık, doğru düşünmeyi sağlıyorsa, bu açıdan Fârâbî'ye göre iki yapı arasında bir benzerlik kurulabilir. Ona göre dilbilgisi çerçevesinde, dilin sözcükler ve referanslarıyla olan ilgisi vardır ve aynı şekilde mantığın da akıl ile akledilenler arasında bir bağlantısı bulunmaktadır. Dil bilgisi, dilsel kullanımda doğru ve yanlışın bir ölçütünü sunuyorsa mantık da düşünme sürecinde Fârâbî'nin kullanımıyla makullerde, doğru ve yanlışın bir ölçütüdür. Fârâbî'ye göre mantık ve dil bilgisi arasında kurulan benzerlik, belli açılardan geçerli değildir. Ona göre dil bilgisi/nahiv, bir millete mahsus konuşma yapısının kanunlarını içerir fakat mantık, bütün dillerde ortak olan kanunları ortaya koymaktadır. Fârâbî, diğer bazı farklılıklara da yer vermiştir. Örneğin mantıkçılar, sıfatlara yüklem (mahmul), mevsûfa, konu (mevzu) adını vermişlerdir..$^{57}$

\subsection{Fârâbî̀ye Göre Mantığın Yapısı ve Temel Kavramları}

Fârâbî̀nin hem pratik hem de teorik bilimler açısından mantığı gerekli bir araç olarak gördüğünü öncelikle belirtmek gerekmektedir. Bu gereklilik, hem bilimlerin içerdiği kavramları anlama, anlamlandırma hem de süreçte oluşacak hatalara karşı bir önlem alma amacını gütmektedir. Fârâbî̀nin mantık felsefesine dair şerh ve açıklamaları, dile getirildiği gibi Porphyry'nin İsagoci'si de dâhil olmak üzere Aristoteles'in bütün mantık külliyatını kapsamaktadır. Bunun yanında onun, mantık ve dil ilişkisi üzerine yoğunlaştığı çalışmaları dikkate değerdir. Fârâbî̉nin bu geniş ilgisi

Fârâbî, "et-Tavtia", el-Mantık inde'l-Fârâbî, thk. Refik el-Acem (Beyrut: Daru'l-Meşrik, 1985), 1/59.

Fârâbî, "et-Tavtia", 55. 
ve çabası, tevarüs ettiği Süryani mantık geleneğinin de yeni kavramlar ve yaklaşımla güncellenmesini içermektedir. Söz konusu seleflerinin, Birinci Çözümlemeler'in neredeyse yarısında durdurdukları mantıksal analizi Fârâbînnin, kesin gerçeği/doğruyu elde etmeye odaklanmış kanıtlamacı yöntemi, sistematik biçimde ortaya koyarak tamamladığı görülmektedir.

Özel olarak, bu bağlamda, Fârâbî̀nin iki konuda derinleştiğini ya da farklılaştığı dile getirilebilir. Bunlar, mantık ve gramer ilişkisinin mahiyeti ile insan düşüncesinde kesinliği sağlayan unsurlar ve bunların mantıksal dizgeyi nasıl biçimlendirdiği ya da şekillendirmesi gerektiğidir. Açıkçası Fârâbînnin mantık ve dil üzerine olan ilgisi, yeni-Aristotelesçi geleneğin felsefe öğretisinin bir parçası olarak ele aldığı mantık ve gramer üzerine olan irdelemelerin, genel bir tarzda çözümüne odaklanmıştır. Daha spesifik ve pratik açıdan, bu yaklaşımın ana motivasyon kaynağı, bir yönüyle mantık ve Arap grameri hakkında ortaya konulan içerik üzerine bina edilmiş tartışmalara yönelik yanıt hedefidir. Evrensel bir meta-dil olarak mantığı savunan Ebu Bişr Mettâ b. Yunus ile Arap gramerinin metodik açıdan Araplara yeterli geldiğini ileri süren Sirafî arasında gerçekleşen tartışma, Fârâbî̀nin söz konusu hedefini gerçekleştirme yolunda somut bir örnekliği ya da hareket noktasını teşkil eder. Modern araştırmacılar nihai noktada, Fârâbî̀nin gerçekten evrensel bir gramer olarak Aristoteles mantığını geliştirme amacını güdüp gütmediği hakkında olumlu ya da olumsuz bir yargıya varmış değillerdir.58 Her ne olursa olsun Fârâbî, mantığı kendi zamanının diline ve kavrayışına uygun terimlerle açılayarak, 'güncelleyerek' onu en azından yerlileştirmeye, kabule şayan bir hale getirmeye gayret etmiş görünmektedir. Bunun da ötesinde Fârâbî̀nin söz konusu yapıyı fikıh ve kelâm disiplinlerine de uygulamaya çalışması, onlar için de kullanışlı bir alet olduğunu göstermeye cesaret etmesi, daha sonra Gazzâlî gibi klasik İslâmî geleneğin önemli simalarından birinin düşüncesinde, “mantık bilmeyenin ilmine güvenilemeyeceği” tezine dönüşmüş̧ür.59 Bu bile başlı başına Fârâbînnin çabasının, düşünce tarihi açısından kısa bir sürede meyvesini verdiğini göstermektedir.

Entelektüel açıdan neredeyse olgunlaşmış bir kültür düzleminde Fârâbî'nin mantığı, özellikle Gazzâlî sonrasında, kesinlik ifade eden yakinî yapıdan başlayarak çıkarımlar ve dayanaklar bağlamında, daha farklı ve daha az değer ifade eden epistemik seviyelere göre geniş bir yelpazede ortaya konulan şekliyle, kanıt teorisi temelinde, her alana bir biçimde hitap etmeyi başarmıştır. Aristotelesçi felsefî geleneğe bağlı kalma adına ödünlerin verildiği yapıda, metafizik ve ilahiyat alanları kesin ilkelere, öncüllere ve çıkarım biçimlerine dayanırken, söz gelimi fıkıh, kelâm gibi alanlar ise daha çok cedelî bir içeriğe sahiptir.60 Öncelikle zihin, iki temel edimiyle yapılandırılmış bir değer olarak, insan türüne özgü biçimde kendini gösterir. Bunlar, kavram üretme ve kavramsal bileşenlerin özel türlerinden yola çıkarak doğrulama, doğru kılma ya da haklı çıkarma olarak, yalın bir şekilde anlatılabilir. İlk kesim olan kavram üretimi, tasavvurât ikinci kesim olan doğrulama ise tasdîkât olarak ifade edilmiştir.

Fârâbî'ye göre öğrendiğimiz şeyler içinde, herhangi bir çıkarım sürecine konu olmadan elde edilenler olduğu gibi rasyonel süreçlerin ürünü olan içerik de bulunmaktadır. Bunlardan ilki, dört kesim olarak ortaya konulabilir: Makbûlât, meşhûrât, mahsûsât ve ma'kûlât-1 evvel. Fârâbî'ye göre

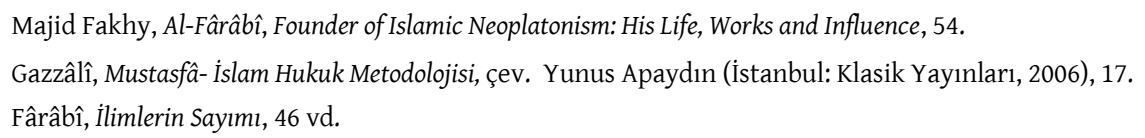


makbûlât, güvenilen bir kişi ya da kaynaktan gelen içeriklerdir. Meşhûrât, genel olarak insanlar arasında yaygın kanaatlerdir (el-ârâu'z-zâia) veya bilginlerin ya da bir alanda uzman olanların onayladığı görüşlerdir. Mahsûsât, beş duyudan herhangi biri tarafından üretilen bilgilerdir. ílk akledilenler ise yapıları itibariyle, yaratılış olarak en başından beri varlığımızda biliniyormuş gibi bir izlenime kapıldığımız içeriklerdir. Bu kesim, kesinlik açısından oldukça önemlidir. Söz gelimi Fârâbî'nin verdiği örneğe göre üç sayısının tek olması, bütünün kendi parçasından her zaman büyük olması vb. hususlar, yakinî bir bilgi olarak, aklımıza kazınmış gibidir. Fârâbî'ye göre, bu tür bilgilerden öncüller elde ederiz ve çıkarım süreçlerinde kullanırız.61

Klasik mantığın, İslâm kültüründe benimsenen tasnifine göre tasdîkât kısmında, önerme ve kıyas konuları, ele alınan temel başlıklardır. Fârâbî'nin aktardığına göre önerme/kaziye öncelikle hamliye/yüklemli ya da şartiye/koşullu olarak ikiye ayrllır. Şartiye, şart harfinin marifetiyle birleştirilen, iki hamliye önermesinden ibaret olan bir yapıdır. Hamliye önermesi ise konu ve yüklem (mevzû ve mahmûl) adı verilen iki ifadeden oluşmaktadır. Her mahmûl ve mevzûda ya lafız bir manaya ya da mana bir lafza delalet etmektedir. Her yapı, ya külli/tümel ya da şahsî/tekil olarak manaya delalet etmektedir. Tümel, birden fazla sayıda varlıklara yüklem olmalıdır. Tekil ise sadece tek varlığa yüklem olur. Önermelerde bazen iki tümel birlikte kullanılır örneğin, "insan canlıdır." Fârâbî'nin ifadesine göre bu tür önermeler bilimlerde, cedelde ve safsata sanatında kullanılır. Parçaları yani mahmûl ve mevzûsu "Zeyd şu ayakta durandır" gibi iki tekil olarak ortaya konulan önermeler ise azdır ve kullanılmaz. Bazen "Zeyd insandır" örneğindeki gibi mevzû, tekil mahmûl ise tümel olabilir. Bu tür önermeler daha çok hitabet/retorik, şiir ve amelî sanatlarda kullanılır. Yine "insan Zeyd, Ömer, Halid...olanlardır" gibi mevzusu tümel, mahmûlü ise tekil/tekiller olan önermeler ortaya konulabilir. Bunlar temsil/analoji ve istikra/tümevarım gibi içerikleri barındıran kıyaslarda kullanılır. Mahmûlü tek şahıs olan, temsilde; tek şahıs değil de birden çok şahıs/eşhas, tekiller söz konusuysa, istikrada kullanılır.62

Cihetli (kiplik) bulunan önermeler de üzerinde durulan yapılardır. Cihet, önermenin yüklemi aracılığıyla ortaya konulan bir niteliktir. Önermede temel olarak cihet, yüklemin konu bağlamında ortaya çıkan konumunun niteliğini (keyfiyetini) ifade eder. Bu çerçevede, mümkün, zorunlu, imkânsız, çirkin, güzel ve bunların çeşitli kalıplarla birlikte kullanımı cihetleri oluşturur. Örneğin Zeyd yürüyebilendir/yürümesi mümkündür ifadesinde yüklem, konusu hakkında ikinci bir yargıda daha bulunmaktadır.63 Fârâbî̀ye göre temelde cihetler üç kesimdir: Zorunlu, mümkün ve mutlak. Zorunlu, varlığı geçmiş ve gelecek bağlamında sürekli olandır. Mümkün ise şu anda olmayan gelecekte ise olup olmaması söz konusu olabilendir. Mutlak ise mümkün kesimin doğasına sahiptir. O, varlı̆̆1 ya da yokluğu olası olduğu halde şu anda ortada bulunandır ve aynı şekilde gelecekte de ortadan kalkabilir.64

Fârâbî̀ye göre kıyas, salt içerimlerinden hareketle zorunlu bir sonuca ulaştıran yapıdır. Sonuca da netice veya redif denilmektedir.65 Fârâbî, kıyas konusunu, yargı üreten süreçlerde ortaya çıkan

\footnotetext{
${ }^{61}$ Fârâbî, "el-Fusûlu'l-hamse", el-Mantık inde'l-Fârâbî, thk. Refik el-Acem (Beyrut: Daru'l-Meşrik, 1985), 63 vd.

62 Fârâbî, "el-Medhal", el-Mantık inde'l-Fârâbî, thk. Refik el-Acem (Beyrut: Daru'l-Meşrik, 1985), 76.

63 Fârâbî, "Kitâbu'l-i̇bâre", 157.

64 Fârâbî, "Kitâbu'l-ỉbâre", 157.

65 Fârâbî, "Kitâbu'l-Kiyâs", el-Mantık inde'l-Fârâbî, thk. Refik el-Acem, (Beyrut: Daru'l-Meşrik, 1986), 2/19.
} 
kafa karışıklığını gidermek ve düşüncelerin ispatı ya da çürütülmesinin yollarını göstermek için ele aldığını ifade etmektedir.66 Mantıkçılar arasında, bu amaçlar doğrultusunda ortaya konulan sanata, kıyas veya delil adı verilmektedir. Öncelikle önermeleri oluşturan unsurlar, kısımları, şartlı ve yüklemli olanları arasındaki farklar dikkatle irdelenmektedir. Diğer yandan mütekabil önermeler ele alınır. Söz konusu yaklaşımda üzerinde durulan diğer konular ise döndürme/aks ve bütün yönleriyle kıyas konularıdır. Bu bağlamda tümevarım, analoji incelenen diğer çıkarım yöntemleridir.

Fârâbî'ye göre, mantık düşüncesi çerçevesinde biçemlenmiş olan Organon külliyatı, konu ve amaçlarına göre birbirinden ayrışır. Fârâbî'nin kabulüne göre beş sanat için yazılmış olan beş kitap, bunların içerimlerine dair genel felsefe ve dayanakların sunulduğu diğer üç kitap göz ününde bulundurulduğunda mantığın parçaları sekiz olarak ortaya konulabilir. Kategoriler (Mekûlât), Yorum üzerine (kitâbu'l-i̇bâre) ve Birinci çözümlemeler (Kitâbu't-Tahlîl, Kitâbu'lKıyâs), genel anlamda mantık sisteminde, dizgesel içeriğe terim ya da kavramları taşıyan bir ambar gibidir. Diğer kitaplar, kesinlik niteliğine sahip içerik açısından epistemik değerine göre ve özellikle kıyas ile onun kullanıldığı alanlar bakımından bir sıralamaya tabi tutulmuştur. Buna göre sırasıyla kesin kanıtlama İkinci Çözümlemeler'de (Kitâbu'l-Burhân), cedelî çıkarım Topikler'de (Kitâbu'l-Cedel), hitabete dayalı amaç ve sanatlar Retorika'da (Kitâbu'l-Hitâbe), mugalâtaya iliş̧in içerik Sofistik Çürütmeler'de (kitâbu'l-Mugalata) ve şiire dayalı, mantığı ilgilendirdiği kadarıyla söz konusu edilen içerik ise Şiir Kitabı'ında ele alınmıştır. Bu sıralama ve bazı içerikleri, Aristoteles yorumcularına dayanır. Aynı zamanda bu dizi, gözetilen amacın akla, hayale veya vehme dayalı insan zihninin çeşitli yetileri çerçevesinde yaratılan düşünce ürünlerinin mahiyetine odaklanıldığını göstermektedir. Bu içerik insan ruhunun, sınırları takdir edilemeyen ontik aynada, kendini kendi gücü orantısında ve kendi yaratım ya da ürünleriyle göstermesinden, görmesinden başka bir şey değildir. Bu ürünler, çeşitli yapılarıyla şeylerin, varlık ve bilgi açısından, düşünce yetisinin verdiği değer bağlamındaki hiyerarşik bir sıralamada, kesinlik niteliğinden başlayarak diğer seviyelerle mühürlenmiş düzeylerini imlemektedir. Bu düzlemde Aristotelesçi gelenekte ve Fârâbî'de mantık, bütün bilimler için amaca ulaşmada, özellikle kesinlik hedefine giden yolda, yöntemsel bir dayanaktır, yaygın betimiyle araçtır.

\section{Sonuç}

Felsefenin, din, bilgi, siyaset ve ahlak gibi temel konularından başlayarak, insan ilgisinin tüm alanlarını kapsayan bütüncül bir yapı olduğu düşüncesi, Fârâbî’nin temel motivasyon kaynă̆ı olmuştur. Diğer taraftan ona göre metafizik kökenleri nedeniyle, daha somut ve cedelî unsurlar barındıran din ile birlikte, hakikatin kaynağı olması düzleminde, Fârâbî için felsefe ve felsefî üretim, bir insanın ulaşabileceği en üst noktayı da imlemektedir. Meşşâ̂ geleneğin, İslâm kültüründeki ilk büyük muallimi olan Fârâbînnin sistemi, aynı zamanda Yeni Platoncu ve İslâmî ögeleri de içeren senkretik, dönemine göre benzersiz, eklektik bir yapıdır. Bu nitelemeler onun, şarih olduğu kadar yaratıcı bir müellif olduğunu da göstermektedir. Bu yaratıcılı̆̆ının dikkat çeken ana unsurları arasında, onun din anlayışı gelmektedir. Fârâbî'nin, din ve felsefe arasında inşa etmeye çalıştığı köprünün temel dayanakları, Tanrı, akıl, nübüvvet, mantık, ahlak ve bilginin

66 Fârâbî, "Kitâbu'l-Kıyâs", 5 vd. 
doğasıdır. İlimlerin Sayımı'nda kavramların epistemik ve ontik düzlemde konum ve işlevini gösteren Fârâbî, hayatı boyunca kurguladığı içeriği, tutarlı biçimde yapılandırıp, bir sistem olarak ortaya koymaya gayret etmiştir. Aristoteles ve Platon'un eserlerinin şerhi bir hazırlık amacını güderken, Erdemli Şehir gibi eserlerde ise felsefenin, ona göre evrensel değerleri, İslâm kültürüne sunulmuştur. Özellikle Fârâbî’nin, metafizik kavramları, İslâm kültürünün kabulüne şayan biçimdeki betimi, geleneksel İslâm inancının doğası ve zamanın sınırlılıkları nedeniyle kapalı kalanı, siyasi ve toplumsal risklere rağmen, aydınlatma çabası onun, din ve felsefe kaynaklı inançlarına bağlllığını gösterdiği gibi, dönemindeki sorunlara çözüm arayan bir filozof olduğunu da teyit etmektedir. Bu çerçevede ahlakın, mutluluk hedefi doğrultusunda kurgulandığına inanan, geleneksel Müslüman inancına paralel olarak, felsefenin katkısı da Fârâbî tarafından ortaya konulmuştur. Bu noktada uzlaşımcı ve yaratıcı yaklaşımı Fârâbî’yi, insan psikolojisini, Tanrı-evren ilişkisini ve bilgi ağını, tek bir sistemde, benzersiz biçimde örüntülemeye teşvik etmiştir. Özellikle mantık, onun sisteminde hakikati keşfeden sağlam bilginin garantörü olduğu gibi, elde edilecek olumlu sonuçlar da insan mutluluğunun nedeni olacaktır. Bütün parçaları birbiriyle tutarlı biçimde ilişkili olan Fârâbînnin yaklaşım ve öğretisi, salt kendi dönemine değil bütün zamanlara yönelik, felsefî veya dini amaçları olan toplumlar için de bir örneklik teşkil etmektedir. 


\section{Kaynakça}

Abdurrezzak, Mustafa. Feylosofu'l-Arap ve'l-muallim-i sani. Kahire: Müessesat-1 Hindevi li'tTalimi ve's-Sakafeti, 2012.

Aristoteles. "De Interpretatione". Complete Works (Aristotle). Jonathan Barnes. New Jersey: Princeton University Press, 1991.

Arsitoteles. Metafizik. çev. Ahmet Arslan. İstanbul: Sosyal Yay., 1996.

Brumberg-Chaumont, Julie. "The Legacy of Ancient Logic in the Middle Ages”. ed. Catarina, Dutilh Novaes - Read, Stephen. The Cambridge Companion to Medieval Logic. Cambridge: Cambridge University Press, 2016.

Ece, M. Nasih. İbn Bâcce Mantığı ve Fârâbî Bağlantıları. Konya: Çizgi Yayınları, 2021.

Endülüsî, Ebü'l-Kāsım Said b. Ahmed b. Said. Tabakâtü'l-Ümem. nşr. Luis Şeyho el-Yesui. Beyrut: 1912.

Fakhy, Majid. A History of Islamic Philosophy. New York: Columbia University Press, 2004.

Fakhy, Majid. Al-Fârâbî, Founder of Islamic Neoplatonism: His Life, Works and Influence. Oxford: One world Publications, 2002.

Fârâbî. "el-Fusûlu'l-Hamse", el-Mantık inde'l-Fârâbî. thk. Refik el-Acem. 4 Cilt. Beyrut: Daru'lMeşrik, 1985.

Fârâbî. Kitâbu Tahsîli's-Saâde. thk. Cafer el-Yasin. Beyrut: Daru'l-Endülüs, 1983.

Fârâbî. "Kitâbu'l-Burhân". el-Mantık inde'l-Fârâbî. thk. Macid Fahri. 4 Cilt. Beyrut: Daru'l-Meşrik, 1986.

Fârâbî. "Kitâbu'l-Kıyâs". el-Mantık inde'l-Fârâbî. thk. Refik el-Acem. 4 Cilt. Beyrut: Daru'l-Meşrik, 1986.

Fârâbî. "el-Medhal", el-Mantık inde'l-Fârâbî, thk. Refik el-Acem. 4 Cilt. Beyrut: Daru'l-Meşrik, 1985.

Fârâbî. "et-Tavtia". el-Mantık inde'l-Fârâbî. thk. Refik el-Acem. 4 Cilt. Beyrut: Daru'l-Meşrik, 1985.

Fârâbî. İlimlerin Sayımı. çev. Ahmet Arslan. Ankara: Vadi Yayınları, 1999.

Fârâbî. Kitâbu Ârâ'i ehli'l-Medîneti'l-fâzılâ. nşr. Elbir Nasri Nadir. Beyrut: Daru'l-Meşrik, 1985.

Fârâbî. Kitâbu't-Tenbîh alâ sebili's-saâde. thk. Cafer Al-Yasin. Tahran: İntişârât-1 Hikmet, 1991.

Fârâbî. Kitâbu'l-Hurûf. thk. Muhsin Mehdi. Beyrut: Daru'l-Meşrik, 1990.

Fârâbî. "Kitâbu'l-i̇bâre". el-Mantık inde'l-Fârâbî. thk. Refik el-Acem. 4 Cilt. Beyrut: Daru'l-Meşrik, 1985.

Fârâbî. Risâle fi'l-akl. nşr. Maurice Bouyges. Beyrut: Daru'l-Meşrik, 1983.

Gazzâlî, Ebu Hâmid Muhammed, Mustasfâ-İslam Hukuk Metodolojisi. çev. Yunus Apaydın. c.1. istanbul: Klasik Yayınları, 2006. 
Hanefi, Hasan. "el-Fârâbî şârihan Aristo". el-Fârâbî fi'z-zikra'l-elfiyyeti livefatihi. nşr. İbrahim Medkur. Kahire: el-Mektebetü'l-Arabiyyeti, 1983.

Hasnawi, Ahmad-Hodges, Wilfrid. "Arabic Logic up to Avicenna", The Cambridge Companion to Medieval Logic. ed. Catarina Dutilh Novaes and Stephen Read. Cambridge: Cambridge University Press, 2016.

İbn Ebî Usaybi'a, Muvaffakuddin Ahmed b. Kâsım b. Halife es-Sa'di el-Hazrecî. Uyunu'l-enbâ fi tabakâti'l-etibbâ. thk. Nezir Rıza. Beyrut: Dar-u Mektebeti'l-Hayat, ts.

İbn Hallikân, Şemsüddîn Ahmed b. Muhammed b. İbrâhîm b. Ebî Bekr. Vefâyâtu'l-ayân. thk. İhsan Abbas. Beyrut: Daru Sadır, 1977.

Kıftî, Ebü'l-Hasan Cemaleddin Ali b. Yusuf b. İbrahim. İhbâru'l-ulemâ bi ahbâri'l-hukemâ. thk. İbrahim Şemseddin. Lübnan: Daru'l-Kütübi'l-îlmiyye, 2005.

L. Colish, Marcia. The Stoic Tradition From Antiquity to the Early Middle Ages: Stoicism in Christian Latin Literature, v. 1. Leiden: Brill, 1985.

Medkur, İbrahim. “el-Fârâbî ve'l-mustalahu'l-felsefî”. el-Fârâbî fi'z-zikra'l-elfiyyeti livefâtihi. nşr. İbrahim Medkur. Kahire: el-Mektebetü'l-Arabiyyeti, 1983.

Nedîm, Ebü'l-Ferec Muhammed bin Ebî Ya'kûb İshak. Kitâbu'l-Fihrist. thk. Rıza Teceddüd. Tahran: у.у., 1971.

Recher, Nicholas. Studies in the History of Arabic Logic. Pittsburgh: University of Pittsburgh Press, 1963.

Reisman, David C. "Al-Fârâbî and the Philosophical Curriculum". The Cambridge Companion to Arabic Philosophy. ed. Peter Adamson ve Richard C. Taylor. England: Cambridge University Press, 2005. 